\title{
Challenges of Future Exploration within the UK Rockall Basin
}

\author{
Nick Schofield', David Jolley', Simon Holford', Stuart Archer ${ }^{3}$, Douglas Watson' \\ Adrian Hartley', John Howell', David Muirhead', John Underhill ${ }^{4}$, Paul Green $^{6}$ \\ 'Geology and Petroleum Geology, School of Geosciences, University of Aberdeen, Meston Building, Aberdeen, AB24 3UE, \\ UK \\ ${ }^{2}$ Australian School of Petroleum, University of Adelaide, SA 5005, Australia \\ ${ }^{3}$ Maersk Oil and Gas A/S, Headquarters, Eplandaen 50, Denmark \\ ${ }^{4}$ School of Geographical and Earth Sciences, University of Glasgow, Gregory Building, Lilybank Gardens, Glasgow, GI 2 \\ $8 Q Q$, UK \\ ${ }^{4}$ Shell Centre for Geosciences, Heriot-Watt University, Edinburgh EHI4 4AS, UK \\ 5 CASP, West Building, I8 I A Huntingdon Road, Cambridge, CB3 ODH, UK \\ ${ }^{6}$ Geotrack International, Brunswick West, Australia, Vic 3055
}

\section{Abstract}

The UK Rockall Basin is one of the most underexplored areas of the UK Continental Shelf (UKCS) with only 12 exploration wells drilled since 1980. With only one discovery made in 2000 (Benbecula (I54/I-I) Gas discovery), the general view of the basin from an exploration viewpoint is not positive. However, over the last 15 years, our knowledge of the petroleum systems of the Atlantic Margin has substantially increased. With the recent acquisition of new seismic data by the UK Government as part of the OGA's Frontiers Basin Research Program, it is a pertinent time to re-examine the prospectivity of the UK Rockall Basin.

This paper presents a history of exploration within the UK Rockall Basin, from the first well drilled in the Basin in 1980, to the last well, drilled in 2006. We then present new insights into the lack of success during exploration within the basin, in particular by focussing on the extensive early Cenozoic volcanic rocks within Rockall, to illustrate the wide range of potential interactions with the petroleum system. We also present evidence that points to the potential of a viable intra-basaltic (Rosebank) type play along the eastern flank of the Rockall Basin.

Introduction 
Although a number of basins along the NW European Atlantic margin, such as the FaroeShetland Basin, have had notable large hydrocarbon finds (e.g. Clair, Foinaven, Schiehallion), the UK Rockall Basin, referred to simply as 'Rockall' throughout the rest of this paper, with only 12 exploration wells drilled since 1980 (compared to the 4272 exploration and appraisal wells drilled on the UKCS since 1965) (Gray 20I3), represents a frontier, underexplored region of the UKCS. The last well drilled in Rockall was over 10 years ago, and exploration success in the area has remained elusive, with eleven dry holes and only one gas discovery, that was deemed sub-commercial at the time (Benbecula South I54/I-I). Coupled with the harsh operating environment of the NE Atlantic which is characterised by short weather windows and long distances from infrastructure and supply chains, this has understandably led to an overall 'negative' view of the exploration potential of the UK Rockall. With the recent acquisition of new Oil and Gas Authority (OGA) funded 2D seismic data in 2014/2015 over the UK Rockall area, and granting of frontier exploration licenses in the $28^{\text {th }}$ licensing round (e.g. OMV), interest in the basin has been renewed.

In this paper we look at the history of exploration in the UK Rockall and examine some of the key geoscience challenges and unknowns concerning future long-term exploration within the basin, applying some of the updated knowledge developed through recent research on the petroleum systems from other areas of the Atlantic Margin (Fig. I), including intra-basaltic plays in the Faroe-Shetland Basin (Schofield and Jolley, 20I3). In particular we argue that some of the existing preconceptions of the basin (e.g. lack of viable source rocks), reasons for dry holes, and understanding of future exploration potential may be incorrect. We also emphasise that although it is important not to become overly focussed on the volcanic sequences within Rockall, the key to fully understanding the prospectivity is the correct integration and understanding of the potential effects that the volcanic rocks within the basin have had on the evolution of the petroleum system. 


\section{Geological History of Rockall}

The detailed geological evolution of the Rockall Basin is still largely unknown, due to the lack of deep well penetrations in the basin, and limited seismic data coverage.

The Precambrian basement likely compromises of two major basement terranes, sutured across the Anton Dohrn Lineament (Doré et al. 1997; Hitchen et al. 2013). The presence of Middle Proterozoic through to Devonian sequences are currently largely unknown in the Rockall area, however the existence of such sequences within the FaroeShetland Basin (e.g. Rona Ridge) suggest that they are probably present within Rockall. During the Silurian to Early Devonian, the Caledonian Orogeny led to compression of the area, resulting in the North East-South West structural grain that has subsequently influenced much of the rift orientation along the Atlantic Margin (Fig. I, 2 and 3) (Hitchen et al. 2013)

Although bathymetrically separated by the Wyville-Thomson Ridge (Fig. I and 2), the NE Rockall Basin is assumed to have undergone a similar rift history to that of the FaroeShetland Basin to the north (Archer et al. 2005). Since the collapse of the Caledonides during the late Silurian-early Devonian a complex multi-phase rift history has evolved. A Late Jurassic to Early Cretaceous rift phase and Late Cretaceous to Paleogene post-rift phase appear to characterise much of the stratigraphy of the Rockall Basin (Musgrove and Mitchener, 1996; Archer et al. 2005). The Rockall, may have become hyperextended during Early Cretaceous rifting, leading to the potential for high segmentation and lack of Jurassic and older sequences towards the centre of the basin (Lundin and Doré, 20I I).

The occurrence of Middle to Upper Jurassic age source rocks, particularly along the basin flanks, is probable, but not proven to be present within Rockall (see next section). Other potential source rock units, e.g. of Carboniferous age, are not proven within the UK Rockall. However, within the Irish sector, Carboniferous source rocks have been proven on 
the eastern flank of the basin (Shannon and Naylor, 2010). The northern extent of these Carboniferous rocks is not clear; onshore, the northernmost extent of Carboniferous rocks along the West Coast of Scotland is seen at Inninmore bay, Morvern, adjacent to the Isle of Mull, comprising of a Westphalian age coal-bearing sequence (Fyfe et al. 1993). However, no other known outcrops are present north of this. Wells drilled onshore and offshore Skye (e.g. I34/5-I, Upper-Glen I) (Fig. 2) only penetrated as far as the Triassic, but Minch-I drilled in the North Minch Basin, $30 \mathrm{~km}$ east of north Lewis (Fig. 2), found a PermianTriassic sequence unconformably overlying the Precambrian, with no trace of the Carboniferous. Therefore although a Carboniferous source in the UK Rockall may be present in the south, it seems unlikely to be present in the north of the basin.

How developed was the Jurassic Rift in Rockall?

Although Jurassic source rocks are proven within the Faroe-Shetland Basin, their presence or absence within Rockall has not been definitively established. The first clearly discernible phases of rifting within Rockall during the Mesozoic are difficult to constrain, with only one well penetration of pre-Cretaceous strata (Permian-Triassic - I64/28-IZ) (Fig 2). However, it is likely that as with much of West of Britain at this time, rifting was potentially first manifested during the Permian-Triassic, with development of narrow, shallow, mostly continental rift-basins (Morton, 1992; Doré et al. 1997; Stolfova and Shannon, 2009). Progressing into the Jurassic, within the Inner Hebrides, significant rifting took place in a series of half-grabens with deposition of thick Early Jurassic and Middle Jurassic sequences (Stein and Blundell 1990; England et al. 1993) (Fig. 2 and 3), and potentially Upper Jurassic, although later uplift and erosion makes discerning this difficult (Holford et al. 20I0).

Within the UK Rockall (Fig. I and 2), the extent of both intra-continental Triassic and then more extensive Jurassic rifting, or nature of the rift geometry, beyond plate 
reconstructions (Cole and Peachey, 1999; Nadin et al. 1999) is not clear. Assessing the areal extent of Jurassic rocks in deeper areas of the basin is still difficult due to the overlying Palaeogene sill complex. Within the Inner Hebrides (Fig. 2), the Triassic-Jurassic succession records an initial deepening from late Triassic fluvial deposits into organic-rich Lower Jurassic marine mudstones. This is followed by shallowing through tide and wave dominated shallow marine clastics (Bajocian), into organic-rich lagoonal and fluvial deposits in the Bathonian (Bathonian - Great Estuarine Group) prior to the global Callovian transgression and a return to Upper Jurassic (Kimmeridigan) marine mudstone deposition (Trewin, 1992).

These marginal to non-marine conditions during the early to mid Jurassic appear, in part, to have extended across the Outer Hebrides landmass towards Rockall, where the shallow borehole $90 / 2$ on the Outer Hebrides Shelf is interpreted to have intersected Bathonian shales (equivalent to the Middle Jurassic Great Estuarine Group in the Inner Hebrides), with high TOC (3.4-8\%), deposited in a lacustrine/lagoonal environment (Hitchen et al. 2013). Although, it is important to note that the Erris/Slyne Troughs and Conemara Field (Jones and Underhill, 20II), located southwards of the UK Rockall and into the Irish sector demonstrate that significant thickness of Jurassic sequences has been deposited offshore, it is not clear whether Lower-Middle Jurassic rocks, or Upper Jurassic (Kimmeridgian rocks) were present in deeper parts of the UK Rockall. Before the advent of plate tectonic theory, the classical UK Jurassic geologists had identified that the North to South seaway connections within the Jurassic were poor, which led to the profusion of stage names (e.g. Volgian and Tithonian) and faunal provinciality, sometimes extreme, throughout the period (see Hallam, 1978). Additionally, unlike the North Sea, which possesses widespread development of oil-prone late Jurassic marine source rock (e.g. the Kimmeridge), oil-source correlation studies along the Atlantic Margin indicate several source intervals ranging in age from Early to Late Jurassic, in facies varying from lacustrine, 
fluvio-deltaic to marginal marine (Scotchman et al. 2016; this volume). These aspects appear incompatible with the development of a major marine seaway along the NE Atlantic Margin, and point to the development of smaller rift basins. It remains possible therefore that the main Jurassic rift and thus deep marine seaway to the West of Scotland, could have developed more extensively within the Inner Hebrides - Sea of Hebrides-Minch Basin, rather than to the West of Hebrides and Rockall (Scotchman et al. 200I) (Fig. 2).

\section{North Atlantic Igneous Province (NAIP) and Rockall Volcanic Sequences}

The Northeast Atlantic witnessed considerable igneous activity prior to, and associated with the onset of sea-floor spreading to the West of the Faroes during the Late Palaeocene to Early Eocene (Naylor et al. 1999; Ellis and Stoker, 2014). The earliest volcanism in the North Atlantic is thought to have occurred around 63 Ma (Hamilton et al. 1998), exposed as the Eigg Lava Formation, Rum, with the beginning of the Faroes flood basalt eruption occurring around 57 Ma ago (Passey and Jolley, 2009).

Volcanic rocks are an unavoidable and integral part of the Rockall Basin, with Northern UK Rockall having the highest concentration of igneous centres, representing focussed igneous plutonic activity, along the entire NE Atlantic Margin. Of the 12 separate centres known in the UK Rockall, four are situated along the eastern and western flanks of the basin margin (not including those of Hatton Bank) and four are present within the axis of the basin (Fig. 2 and 3). In addition to these centres, an extensive lava sequence and a pervasive sill complex exist throughout the basin, but the sill complex appears to be less prevalent above structural highs.

Penetration of the North Atlantic Igneous Province (NAIP) extrusive volcanic subcrop is restricted to $\sim 43$ exploration wells along the Atlantic Margin. Because of this, the Faroe Islands Basalt Group (FIBG), located proximal to the rift centre, is of primary 
importance in preserving sedimentary, extrusive and intrusive igneous strata that illustrate the range of depositional systems and eruptive styles that operated during the eruptive period of the NAIP (Passey and Jolley, 2009). Importantly, Schofield and Jolley (2013) highlighted that within the FSB, changes in lava field stratigraphy and nature of eruption facies seen onshore the Faroes (Fig. 4), are generally replicated across the basin. Correlation of the FIBG stratigraphy to the time-equivalent volcanic and sedimentary sequences of the Faroe-Shetland Basin has demonstrated stratigraphical continuity, which is constrained within the regional sequence stratigraphy (Ebdon et al., 1995; Passey and Jolley, 2009; Schofield and Jolley 20I3).

Here, we present new palynological and seismic stratigraphical analysis showing that within Rockall, the extrusive volcanic sequences, penetrated in wells, are age equivalents of part of the Faroe-Island Basalt Group (FIBG) and correlative eruptive sequences around the NE Atlantic. Extrusive lava sequences (often referred to as the 'Upper Rockall' and 'Lower Rockall' lavas) penetrated by wells in the NE Rockall (e.g. 164/25-2, I54/3-I) include sedimentary interbeds that have yielded marine and terrestrial palynofloras attributable to sequence T40 Flett Formation (56.I Ma - 55.2 Ma). These volcanics are age equivalent to the Beinisvørð Fm., the maximum effusion rate lava pile at the base of the FIBG (Fig. 4 and 5) (Passey and Jolley, 2009). Additionally, separately sourced, but age correlative sequence T40 volcanic strata have been recorded along the Corona Ridge in the Faroe-Shetland Basin, were basaltic lavas and their sedimentary interbeds form the reservoir rocks and seals of the Rosebank Field. Understanding the age of the Rockall Basin volcanic sequence clarifies the coeval nature of volcanism across the NAIP. Volcanism in Rockall was coeval with separately sourced eruptions from the Faroe Islands, Vøring Plateau, Corona Ridge and the Inner Hebrides (e.g. Mull). 
Importantly, the Rockall wells drilled to date do not penetrate any Sequence T45 (Upper Flett Fm.) equivalent strata. Lava successions of this age are recorded in the FaroeShetland Basin, forming the upper part of the FIBG and extensive locally sourced sequence T45 lava fields on the Corona Ridge (Schofield and Jolley, 2013). Evidence from FIBG basalt geochemistry indicates that ocean floor emplacement had commenced in late Sequence T40 time (Hole et al. 20I5). This indicates that magmatic activity contracted and shifted further to the north and west along the nascent North East Atlantic Rift. The migration of the magmatic system, allied to the well penetration data, demonstrates that the extrusive eruptive system on the eastern flank of Rockall had largely shut down by the end of Sequence T40 (55.2Ma), while eruption of lava was still continuing in the FSB (Schofield and Jolley, 20I3). Interestingly, along the western flank of Rockall, towards the Hatton Basin, adjacent to the George Bligh Igneous Centres (Fig. 2) magmatism in the form of volcanic edifices is evident from seismic data, with one edifice being $6 \mathrm{~km}$ in width and $\sim 800$ metres in height (Fig. 5).

\section{UK Rockall Hydrocarbon Exploration Summary}

To understand the exploration challenges of the UK Rockall, it is important to assess some of the key wells drilled in the region chronologically, and examine how knowledge of the basin and petroleum system evolved into its current state. A total of 12 exploration wells have been drilled in the UKCS sector of the Rockall (Fig. 2). All these wells, aside from I54/I-I, were dry, although I64/28-IA did encounter oil shows.

Exploration within the UK Rockall falls mainly into two main phases (Fig. 6). The first phase from 1988 until 1992 was characterised by highly frontier rank wildcat exploration, which led to five wells being drilled (four by BNOC/BP and one by Conoco) with no discoveries, but allowing for some subsurface geological control and knowledge to be established. The second phase, from 1997 until 2003, was more targeted, and saw the basin 
being entered by other operators such as ENI, Enterprise and Shell, with exploration aimed at four-way dip closures along the eastern margin of the basin. Between 2000 and 2003, the UK Rockall underwent an 'intensive' exploration period, with five out of the total 12 wells drilled in the area during this time.

The last exploration well drilled (as of 2016) in the UK Rockall was in 2006 by Shell. The summary below, of a number of key wells is collated mainly from released well data and reports, and the work conducted both by operators and contractors is acknowledged.

\section{(1980) I63/06-IA - The first stratigraphic test well in Rockall}

The first well drilled in the Rockall was in 1980 by BNOC, and was designed to test stratigraphy of the basin and establish the presence of any hydrocarbon system, as up to this point no subsurface information was available for Rockall. The primary objective of the well was to evaluate a proposed Mesozoic foreset succession, which was assumed to be sedimentary in origin, at approximately $4165 \mathrm{~m}$ subsea, that had been identified from regional $2 \mathrm{D}$ seismic data.

Upon drilling, the well encountered a sequence of Eocene and Palaeocene siltstones before penetrating nearly I km of extrusive basalt before the well was abandoned (Morton et al. 1988). No sign of hydrocarbons were found in the well. Although the 'foreset' succession was not reached in the well, in hindsight, given the volcanics encountered in this well, across the basin (e.g. 164/7-I), and wider Atlantic Margin (Wright et al. 2012), it would appear that the foresets identified in the pre-well prognosis were likely to be a series of prograding volcanic lava-hyaloclastite packages, rather than any clastic sedimentary system.

(1988) - I64/25-Iz - Second well and rank wildcat to test Jurassic to Eocene sandstone intervals 
Well 164/25-Iz was drilled in 1988 by BP targeting a four-way dip closure located to the east of the faulted high of the West Lewis Ridge (Fig 2 and Fig. 7). At the time of drilling, the nearest wells were located 130 and $190 \mathrm{~km}$ away, and it was recognized that the pre-drill stratigraphic prognosis was highly speculative.

Upon drilling, the well penetrated a series of Palaeocene and Eocene sedimentary strata, before entering an extrusive volcanic sequence. The well then encountered a series of Lamba Fm. and Vaila Fm. equivalent sequences, before penetrating into the Cretaceous. Significantly, the Cretaceous was found to unconformably overlie the Permo-Triassic, with no Jurassic present. Arguably, the lack of a Jurassic succession overlying the Permo-Triassic within this well is a key finding that triggered doubts concerning the presence and areal extent of Jurassic source rocks West of Hebrides. This aspect was further emphasised by well 164/25-2 (drilled in 1990 by BP), which was located $10 \mathrm{~km}$ to the north of well $164 / 25$ Iz, along the West Lewis Ridge. After encountering a thick ( 400m) sequence of Palaeocene lavas and intra-volcanic clastic sequences (discussed later in the paper), this well penetrated directly into crystalline Caledonian basement (Musgrove and Mitchener, 1996).

(1991) - I32/I5-I First well to test a hydrocarbon prospect in the Southern UK Rockall

Well I32/I5-I, drilled in 199I by BP, was designed to test the hydrocarbon potential of a large pre-rift tilted block and other secondary syn- and post-rift targets (Fig. 8). The well formed the first test of hydrocarbon viability of the southern extent of the UK Rockall, with the nearest offset well being $85 \mathrm{~km}$ to the south in Irish waters.

Upon drilling, the pre-rift block was found to comprise of crystalline Caledonian basement (Musgrove and Mitchener, 1996), overlain by Cretaceous strata, with no occurrence of older strata (e.g. Jurassic). No hydrocarbons or shows were encountered in 
the post rift sequences, and no reservoirs rocks found within the Cretaceous megasequence, which comprised mainly of mudstone with occasional limestone sequences and intrusive sills.

Within the Vaila Fm. equivalent section, a $50 \mathrm{~m}$ thick volcaniclastic sandstone was encountered that was reported to contain pebbles of granite, felsite and basalt, indicating potential sourcing of material from the Igneous Centres along the West coast of Scotland (e.g. Mull, Skye, Ardnamurchan etc.).

\section{(1997) I64/7-I 'Dome prospect' - First sub-basalt well}

The 'Dome' prospect was drilled by Conoco in 1997 (Archer et al. 2005), marking the second phase of exploration in Rockall after a 6 year hiatus. The prospect was designed to test a four-way sub-basalt closure that had been identified on regional 2D seismic lines (Fig. 9). The pre-well prognosis was that of a rollover anticline consisting of a series of interbeded shales and sandstones. However, upon drilling it was found that the thickness of the extrusive package was over twice the thickness which had been predicted in the predrill interpretation (518m predicted vs. $1165 \mathrm{~m}$ actual). This discrepancy was largely down to the presence of a thick sequence of relatively low-amplitude hyaloclastites below the subaerial lava sequence. In the pre-drill interpretation this facies change had been wrongly interpreted as the contact between the volcanic and underlying sedimentary sequence. On exit of the $1.2 \mathrm{~km}$ lava pile, the thick Cretaceous section was found to be heavily intruded by sills (approximately $70 \%$ sills to $30 \%$ host rock), and it was discovered that the subvolcanic reflections, which predrill were thought to be the result of interbedded shale and sandstone sequences, were in fact caused by dolerite sills intruded into shale. No sand bodies were encountered in the entire $1.8 \mathrm{~km}$ thick sub-volcanic Cretaceous section (Archer et al. 2005). 
(2000) I54/I-I (Benbecula South) - Rockall's first and currently only hydrocarbon discovery

Benbecula South (I54/I-I) was drilled during April and May of 2000 by Enterprise Oil, and the primary objective of the well was to establish hydrocarbons in Palaeocene sands in a four-way dip closure (Figs. 7, 9, I0 and II). The well encountered a 54 metre gas column within Vaila Fm. sandstones, though no traces of liquid hydrocarbons were found in. The seal comprised of shale and an overlying hyaloclastite unit.

Isotopic analysis was carried out on the gas, and it was stated that Benbecula South gas possessed a 'very unusual isotopic signature' with the favored explanation that the gas is a mixture of a small amount of normally generated "oil associated" gas, plus a more extensive amount of dry methane caused by extensive "oil to gas" cracking, potentially caused igneous intrusions. The fact that Benbecula intersected a gas column proves that Rockall does possess a source rock capable of generating hydrocarbons.

\section{(2000) 164/28-I A - Oil shows and geochemical signature of potential source rocks}

Well I64/28-IA was drilled from May to July of 2000 by ENI, coeval with Enterprise's Benbecula $(154 / I-I)$ well. The well had three separate targets in a broad four-way dip closure, although in the deeper Vaila Fm. section, the closure is less well defined (Fig. 8 and 10). Upon drilling, the well was found to have oil shows within the Vaila Fm. sequences, but with no associated gas.

To date, I64/28-IA is the only well within the UK Rockall to contain traces, in the form of staining, of liquid hydrocarbons. Geochemical analysis of the oil shows, particularly in the lower section of the well $(2864-3169 m)$, indicate a relatively anoxic marine source with significant terrestrial input, with the results noted as being fairly similar to Upper 
Jurassic marine source rocks in the North Sea (Draupne/Kimmeredge Clay Fm.). This analysis is also currently the only potential indication that mature Upper Jurassic source rocks may be present at depth and have generative potential within the UK Rockall.

\section{(2002) I64/27-I - Lack of success with the Vaila Fm. play}

Well 164/27-I was drilled during winter conditions from October to late December 2002, to test the Antaeus prospects, a well-defined four-way dip closure, situated down dip from 164/28-I A (Fig. 7 and 10).

The Antaeus prospect consisted of a prognosed wedge of Vaila Fm. sands thought to have been shed into the basin from the Outer Hebrides platform. Upon drilling, the pre-well prognosis of the stratigraphy was largely correct, but the Vaila Fm. sand package was found to contain no hydrocarbons.

Due to poor weather conditions associated with drilling during the beginning of winter, the well lost a total of $\sim 43$ days waiting on weather, related to the need to wait for suitable sea conditions for anchor handling. On reaching TD in early December, approximately $2 \mathrm{I}$ days of waiting for suitable conditions was needed before the rig could be demobilised from the well site. However, the well does highlight that winter or late season drilling is still possible in the harsh and unsheltered metaocean conditions of Rockall, albeit with issues associated with anchor handling.

(2006) I 54/I-2 (Benbecula North) Final well and cessation of exploratory drilling in the basin

After the discovery of gas in Benbecula South (I54/I-I), I52/I-2 (Benbecula North) was drilled by Shell in 2006 to test the northern extent of the broader four-way dip closure that was penetrated by I54/I-I (Fig. 7 and 10). Upon drilling, although a similar thickness of 
Vaila Fm. sands were encountered, no hydrocarbons were detected, with the sands being found to be water wet. This well was the final well drilled within the UK Rockall to date.

\section{New insights into the UK Rockall Plays}

The following section deals with some of our current knowledge of the petroleum system of the UK Rockall and provides new insights into the Rockall petroleum system based on knowledge developed within other areas of the Atlantic Margin (e.g. FSB), particularly with respect to the interaction of the petroleum system with volcanic sequences along the Atlantic Margin.

Have we overestimated the gross thickness of the Cretaceous sedimentary pile in Rockall?

Understanding when peak oil/gas generation occurred within the UK Rockall is a critical aspect of understanding the petroleum system and defining new plays within the basin. However, with no well penetrations of probable source rock strata (e.g. Kimmeridge Clay Fm. equivalent or other source rocks units), basin modelling is challenging, and is reliant on accurate interpretation of the overburden and burial history of the basin.

Along the Atlantic margin, the deposition of large thicknesses of Cretaceous sequences burying the Jurassic source kitchen has long been a key and accepted part of basin modelling (Illife et al. 1991; Scotchman et al 2006). Such models have often been faced with issues of 'early' hydrocarbon generation, which appears incompatible with the occurrence of certain fields along the Atlantic Margin, which would require 'late' hydrocarbon generation (Scotchman et al. 2006).

However, Schofield et al. (20I5), highlighted through well and seismic analysis in the Faroe-Shetland Basin that basin models may have drastically overestimated the true 
thickness of the Cretaceous sedimentary section along the Atlantic Margin prior to the midlate Palaeocene.

The Atlantic Margin basins, including Rockall, are heavily intruded by sills of the Atlantic Margin Sill Complex (e.g. Fig. 8) (e.g. Magee et al. 20I4). Within the UK Rockall, as along other areas of the Atlantic Margin, the sill complex can often be seen to preferentially exploit the mud-rich Cretaceous sequences, often obscuring any deeper lithology or structure on seismic data, even in the areas of the margin not covered by extrusive basalt.

Due to the relatively deep level of the Atlantic Margin Sill Complex within the contemporaneous basin fill ( 3 seconds TWT and below), and accompanying decrease in seismic resolution, potentially only $10-15 \%$ of the total sill intrusions within the Cretaceous section are being clearly resolved in seismic reflection data. Although the remaining intrusions are thin and often seismically unresolvable, cumulatively they form a large thickness of igneous material (potentially in the region of $1.5 \mathrm{~km}$ in the Faroe-Shetland Basin; Schofield et al. 2015).

This raises the possibility that the thickness of the sedimentary component of the Cretaceous succession along the Atlantic Margin, and Rockall (e.g. Fig. 8), has been considerably overestimated in previous studies. A large proportion of the current thickness, presumed to be all sedimentary (ca. $2-2.5 \mathrm{~km}$ in thickest parts), could actually be composed of primary igneous material in the form of unimaged end-Cretaceous to Palaeocene aged sill intrusions (Schofield et al. 2015), with the total thickness of the apparent Cretaceous seen within seismic reflection data being a function of both a Cretaceous sedimentary component and a Palaeocene intrusive volcanic component. This scenario has profound implications for basin modelling, sediment budget calculations and gravity interpretations of the Rockall area, because the thickness of intrusions needs to be removed from models in order to correctly 
represent the true thickness of the Cretaceous sedimentary pile prior to sill emplacement during the Palaeocene.

Importantly, with regard to basin modelling and petroleum generation, it has been identified that basin modelling along the Atlantic Margin has often led to the pre-Palaeocene generation of hydrocarbons (Iliffe et al. 1999; Scotchman et al. 2006). To explain the presence of hydrocarbon discoveries along the margin in Palaeocene (and later) reservoirs and traps, it has been proposed that various mechanisms acted to 'delay' the migration of hydrocarbons into reservoirs. The so-called 'hydrocarbon hotel' model, which involves two stage migration (lliffe et al. 1999) or Cretaceous overpressure to retard hydrocarbon migration (Scotchman et al. 2006) has gained prominence as an explanation for this complicated migration history suggested as a potential mechanism. However, if Cretaceous sequences are thinner than previously assumed in Rockall and parts of the Atlantic Margin, source rocks will have reached maturity and begun generating hydrocarbons later than previously estimated (lliffe et al. 1999). This might remove the need to invoke models to delay migration and explain why many basin models along the Atlantic Margin have not been reliable, or only worked over limited geographic areas.

Failures of the Vaila Fm. Play and potential for new Vaila Fm. stratigraphic trap play against Outer Hebrides Shelf/West Lewis Ridge

With discovery of gas within Benbecula South (I54/I-I) within Vaila Fm. sandstones, the Vaila Fm. play is currently the only proven hydrocarbon play within the UK Rockall. However, further success in wells that have targeted this play has remained elusive (e.g. I64/27-I, I54/I-2, I64/28-IA) 
Although well 164/28-IA found evidence of oil shows in the Vaila Fm. sandstones, the closure at the Vaila Fm. level of I64/28-IA is only three-way, with the well penetration of 164/28-I A appearing to be towards the edge of this closure (Fig. II).

Furthermore 164/28-IA was drilled to the edge of a large transgressive sill complex (Fig. 12). Within the Rockall, as with the FSB, the Vaila Fm. play is often subject to close association and juxtaposition with the Atlantic Margin Sill Complex. In the FSB there is a strong relationship between the some of the hydrocarbon fields (e.g. Tormore) and the underlying sill complex (Schofield et al. 2015), with the sills, potentially having acted as fractured conduits and migration routes to hydrocarbons, leading to charging of Vaila Fm. sequences along the Flett Ridge (e.g. Fig. I 2 c and d; Tormore, FSB)

In basins with high densities of sill intrusions like Rockall, well data suggest that prospects that are targeted directly overlying the sill complex, rather than at its edges, have often been subject to poor or no hydrocarbon charge (e.g. I64/27-I) (Fig. I2e), due to hydrocarbons being potentially baffled away from the tips of the sills and migrating to other areas of the basin (Rateau et al. 2013; Schofield et al. 20I5).

Within Rockall, a similar scenario appears to apply to I64/28-IA, with a sill tip extending up to the up-dip Vaila Fm. sequences of that penetrated in 164/28-I A (Fig. I2). By analogy with the FSB, the sill could potentially have acted to charge the up-dip Vaila Fm. sands to the east of the closure of I64/28-IA, leaving I64/28-IA on the edge of a "shadow zone' of hydrocarbon migration (cf. Rateau et al. 20I3).

The baffling and possible movement of hydrocarbons updip within the Vaila Fm. sandstones, brings potential for a stratigraphic play against the Outer Hebrides shelf/West Lewis Ridge (Fig. 12), a play type that has not been currently tested within the Rockall.

One element of note in favour of this play, is that the overlying Palaeocene hyaloclastites which can be seen to have built out away from the then sub-aerial shelf of the 
Outer Hebrides, can act as particularly good sealing units, due to the breakdown of unstable mineral phases to clays during diagenesis (Watton et al. 20I4; Rawcliffe, 20I5).

The role of forced folds in trap creation in the Rockall As discussed in earlier section of this paper, much of the second phase of exploration within UK Rockall from 1997 to 2006 was targeted at four-way dip closed structures in the basin. Although such targets are obviously attractive in an exploration sense, it is however important to explore the origin and formation of some of these structures

Wells drilled on the eastern flank of the UK Rockall, including that of the Benbecula discovery well, all have close association with underlying intrusions and in several cases it appears that the four-way closures targeted by wells within the basin, actually have their origin as a result of formation of 'forced-folds' caused by underlying intrusion and 'jackingup' of the overlying strata (Fig. 7).

The four way-dip closure penetrated by 164/25-Iz, drilled in 1988, was interpreted prior to drilling as a hanging-wall anticline developed over a Palaeogene aged-inversion structure on the West Lewis Ridge (Fig. 7a). New data over 164/25-Iz shows a four-way closure underlain by saucer-shaped intrusions, which were also penetrated by the well. The closure of the structure conforms to the underlying intrusions, and the nature of folding and closure closely matches that seen in other forced folds documented along the Margin (e.g. FSB: Schofield et al. 2015), and previously interpreted in Rockall (Hansen and Cartwright, 2006). We therefore interpret that the closure penetrated by $164 / 25-$ Iz was mainly created by the underling intrusions jacking up the overlying sequences. It is noteworthy that within the geological well evaluation report produced after the well was completed, a reference is made that the sills penetrated in the well were 'invoked as the possible cause for the inversion feature' as a result of 'jack-up'. Truncation of folded Ypresian age lower Balder 
Fm. sequences against the overlying Top Balder marker is observed, indicating that the intrusion of the underlying sills, and formation of the forced fold took place during Balder Fm. times (Ypresian; sequence T50 - 54.9Ma to 54.3Ma). This post-dates the documented final eruptions of lava on the Eastern flank of the Rockall, which had largely ceased by end of Flett Fm. times (Ypressian; sequence T40 - 56.IMa 55.I Ma), and suggests that intrusive magmatism was still taking place in the Rockall after extrusive volcanism had ceased.

Well 164/27-I was drilled on a well-defined four-way dip closure (Fig. 7b), however, the origin of this closure, named Antaeus, appears to be at least in part connected to an extensive complex of underlying saucer-shaped sills, which correspond closely to the largescale overlying dip closure. The intrusions have induced both localised folding, above individual intrusions, but cumulatively as has been shown in the Irish Rockall (see Magee et al. 20I4), a series of intrusions can act together to cause uplift and formation of 'compound' or interference folds, which results in a broad closure, such as that seen with Antaeus.

Both the Benbecula South discovery $(154 / I-I)$ and the separate structure of Benbecula North (I54/I-2) have an extensive sequence of underlying sills (Fig. 7c and II), though unfortunately clear imaging of these sills and associated strata is challenging due to the overlying volcanic sequences. However, the four-way dip closures of Benbecula South and North, do appear to conform to the extent of the underlying sill complex, and the dips of the overlying sequences suggests that at least, in part, the closures are linked to the underlying sill complex.

Although four-way dip closed structures created by intrusion of sills may form an attractive exploration target, as appears to have been the case in the NE Rockall, they are not necessarily ideal targets, due to the potential of having no hydrocarbon migration and charge into the trap (Holford et al. 2012). In the same way that intrusions may act as fractured migration conduits into a potential updip prospect/or stratigraphic trap (e.g. 
Tormore, FSB), hydrocarbons might also be baffled away to the edges of a trap, if it is underlain by intrusions. This scenario will be particularly acute over four-way dip closures which are underlain and/or created by a saucer-shaped sill, as the sub-circular nature of the sill rim will tend to baffle hydrocarbons away on all sides from the overlying four-way dip closed trap. Indeed, by applying the above principle in terms of hydrocabon migration, and inspecting the prospects drilled in the Rockall (see Fig. 7) in this context, it is perhaps not surprising that no hydrocarbons were found in either $164 / 25-1 z, 164 / 27-1$ or $154 / I-2$ (Benbecula North), if the underlying intrusions were acting as efficient migration conduits or barriers to hydrocarbons.

Interestingly, underlying the discovery of Benbecula South (I54/I-I), a sill can be seen climbing sub-vertically through the Cretaceous section and Palaeocene Vaila Sst. on the eastern flank of the trapping structure (Fig. II). Critically, it would appear that the sill tip cuts up through the Vaila Fm. reservoir sandstone of Benbecula, offering a potential charging route into the four-way trap and a lateral barrier to back filling of the I54/2-I structure.

In summary, four-way dip closures within Rockall may form attractive targets but they should be avoided if they result from underlying sill intrusion unless a viable migration pathway into the trap can be established, as with the Benbecula discovery (see Fig. II)

Poor Vaila Fm. Play Sandstone Quality and Hydrothermal Fluids

Within the Faroe-Shetland Basin, a major risk to the Vaila Fm. sandstone play is reservoir quality, due to its relatively deep $(>3.5 \mathrm{~km})$ level of burial, quartz cementation is common. Higher porosities (20\%) have been preserved at depths greater than $3.5 \mathrm{~km}$ within the FSB as a result of chlorite overgrowths (Kheidri et al., 20I4) (Fig. I3 and I4). Within Rockall the Vaila Fm. sandstones can have pore-infilling calcite and kaolinite cements, with Benbecula South $(I 54 / I-I)$ possessing lower than expected porosity ( $19 \%$ compared to the $\sim 25 \%$ 
expected) (Fig I3 and I4). Importantly, similar carbonate cementation is uncommon within the Vaila Fm. of the FSB.

The FSB and Rockall were not connected during the Palaeocene, and are thought to have been separate basins (Hitchen et al. 2013). It is therefore likely that different depositional environments were present in each basin, particularly within the shelfal source areas for the Vaila Fm. turbidites. Decreased clastic input and increased biotic activity within the UK Rockall relative to the FSB could have led to a greater volume of carbonate deposition in shelfal and basinal areas, which during diagenesis may have promoted porefilling calcite cementation.

An alternative explanation for the carbonate cement found within the Vaila Fm. sequences of Benbecula South (I54/I-I) may be related to hydrothermal fluid precipitation (e.g. hydrothermal calcite-kaolinite bleached porous sandstone; Grove, 20I4). Apatite fission track and fluid inclusion analysis undertaken on I54/I-I, show that Vaila Fm. sequences experienced substantially increased palaeotemperatures compared to surrounding rock (up to $240^{\circ} \mathrm{C}$ ), interpreted to be the result of hot fluid migration through the reservoir sequence (Fig. I5). As discussed previously, the Vaila Fm. sandstone in the Benbecula discovery can be seen to be cut by intrusions, particularly to the east of the trapping structure, offering a potential source for the hot fluids.

Additionally, I54/I-I is located $\sim 90 \mathrm{~km}$ away from both the Rosemary Bank and Darwin Igneous Centres (see Fig. I5), and it seems plausible that these centres would be associated with basin-scale convective heat flow systems, which would have preferentially flowed through high porosity reservoirs such as the Vaila Fm. sandstones. It can therefore be assumed that along the eastern margin of the UK Rockall, the same relationship displayed in I54/I-I could affect the Vaila Fm. plays elsewhere and reduce potential porosity and permeability. 
It is an important consideration to note, that in an exploration sense, targeting of reservoirs with the highest porosities and permeability is desirable. However, these high porosity and high permeability reservoir units, in volcanic affected basins, will also be preferentially exploited by hot hydrothermal fluids, as Benbecula illustrates. However, even if flushing of reservoir sequences has occurred by relatively hot hydrothermal fluids $\left(>240^{\circ}\right.$ C), porosity and permeability can still be preserved to form a viable reservoir.

Intra-Basaltic (Rosebank) Play - A new play type of play for the UK Rockall?

The discovery of the Rosebank intra-basaltic field in 2004 within the Faroe-Shetland Basin, opened up a new (but geologically complicated) play type in the Atlantic Margin. Schofield and Jolley (20/3) identified that a major challenge to the viability and potential extent of the play was the need to input large amounts of 'clean' (i.e. non-primary volcanically derived) siliciclastic material from outside of the lava field. This is because volcaniclastic material generated within the lava fields tends to result in poor reservoir quality following burial, due to unstable mineral phases that degrade porosity and permeability during diagenesis (Helland-Hansen 2009; Schofield and Jolley, 20I3; Clark, 2014). Within the Faroe-Shetland Basin, this has led to what is potentially an areally restricted play fairway on the Corona Ridge, due to the limited zones in which 'clean' sand can be supplied into the lava field due to long distance of transport required from the Shetland platform (across what was the emergent to shallow shelf of the Faroe-Shetland Basin at this time).

Within the Rockall, with respect to reservoir quality, the intra-basaltic play potentially has even more viability on the eastern flank of the Rockall Basin than within the FSB. This is due to the proximity of the Rockall lava sequences against the Outer Hebrides and Scottish landmasses (Fig. I, 2 and 3), which would have provided a consistent 'clean' 
clastic source over considerable distance down the eastern margin of the UK Rockall Basin, shedding clastic material across the shelf and into the basin (Fig. I6).

Biostratigraphical correlation between the Rosebank intra-basaltic sequences (well 213/27-2) and Rockall wells 164/25-2 and I54/3-I importantly shows that the Flett Flett Fm. Colsay member equivalent intervals can be recognised within the Rockall wells (Fig. 5). Significantly, the potential for thick intra-basaltic Colsay Mbr. equivalent sediments is highlighted in well 164/25-2, which encountered 150m thick of porous siliciclastic Colsay (Flett Fm.) equivalent section (although this clastic unit is wrongly classified in the original released well data as Lamba Fm.) (Fig. 9). This sequence can be traced up dip, where it pinches out towards the Outer Hebrides Shelf/West Lewis Ridge. Towards the basin depocentre, the sequence appears to thicken away from the West Lewis Ridge into the NE Rockall Basin.

Therefore within the Rockall, we suggest that opportunity exists for exploiting a potential Colsay Mbr type play, and it is interesting to note that the $150 \mathrm{~m}$ thickness of clastic rich Colsay Mbr equivalent strata penetrated by $164 / 25-2$ is considerably thicker than any individual Colsay packages penetrated within the Rosebank Field, which are in the region of I0's of metres and also interbedded with lava flows. Additionally, in common with the Colsay Mbr of Rosebank, excellent porosity of up to $35 \%$ and permeabilities of over 8 Darcys are present in this sequence within the North East Rockall.

Issues with stratigraphy and lithological descriptions of current released well data A major issue with the UK Rockall is that in many cases the current litho- and biostratigraphy in the UK Rockall is erroneous and inconsistent between wells, particularly for Paleocene and Eocene sections. A significant problem is that previous biostratigraphic work appears to have been done in isolation, lacking integration with lithological or other 
data. The potentially biggest cause of issues with the stratigraphic correlation between wells, however, appears to be that during the second phase of exploration in the UK Rockall, between 2000 and 2003, five wells were drilled by four different operators. With each well being drilled concurrently prior to the data release of the surrounding offset wells, this has led to a lack of consistency in stratigraphy between wells.

As an example of erroneous issues with released well data in Rockall, the well completion lithological interpretation for $154 / 3-1$ is broad and defines what is simply a volcanic facies change as a major stratigraphical boundary. This error is compounded by subsequent biostratigraphical analyses of this well which derived erroneous Vaila Fm. and Balder Fm. equivalent lithostratigraphy for the volcanic sequences. Our subsequent primary biostratigraphical analysis has identified all the extrusive volcanics in this well as falling within Sequence T40, (Flett Fm.) in age, with a clear Colsay Mbr. signature in the well.

It is clear that for Rockall to be successfully explored, the current issues with the well data need to be addressed, with the stratigraphical and lithological analysis being standardised between wells and placed in a proper Atlantic Margin regional stratigraphic context.

\section{Conclusions: Future Challenges and Outlook for the Basin}

Has the petroleum potential of Rockall really been tested to date?

With only 12 exploration wells, the UKCS Rockall Basin remains truly frontier and a high exploration risk. With only one discovery out of 12 wells, the basin has not been an attractive exploration target to many companies. We would argue however, that the above statistics are misleading. Out of the 12 wells drilled, three wells (I53/3-I, I63/6-Ia and I64/7-I) can be discounted as not representing proper tests of the UK Rockall petroleum 
system, as they were drilled on limited or incomplete geological data at the time, which led to substantially incorrect pre-drill interpretations and invalid targets.

Out of the remaining nine wells, four of those wells have either been drilled on forced folds created by intrusions, or strongly associated with underlying intrusions, which may have led to issues with little or no hydrocarbon charge into the traps $(164 / 25-1 \mathrm{z}$, I64/27-I, I64/28-IA and I54/I-2). Therefore out of the I 2 wells drilled, we only regard five wells as having potentially successfully tested an element of the petroleum system within Rockall (I32/6-I, I32/I5-I, I54/I-I, I64/25-2, I53/5-I).

We thus argue that the petroleum potential of Rockall has not been tested properly to date and as highlighted in the previous section, considerable new knowledge can be brought into the basin by applying geological learnings from other areas of the Atlantic Margin.

The potential of a stratigraphic Vaila Fm. play on the eastern flank of the UK Rockall against the Outer Hebrides Shelf is currently untested, but potentially forms a target which may mitigate issues with baffled hydrocarbon migration with Rockall (see previous sections; 164/28-IA). The possible Colsay Member play also deserves attention, as it was not recognised during the previous two exploration phases within the basin.

\section{Exploration outlook for the UK Rockall}

The UKCS is competing on a global scale for exploration, and this, coupled with the current low oil price (2016 average $\sim \$ 42)$, has led many companies to exchange technical risk for sovereign risk in other global offshore areas. Therefore, with Rockall being far from infrastructure and geologically challenging it is clear exploration within Rockall may not initially appear attractive. 
With only 12 exploration wells in 36 years, the exploration interest compared to other areas of the UKCS has never been substantial. However, we have highlighted several aspects for future consideration within the UK Rockall, and importantly highlight that much of the lack of exploration success has been, at least in part, potentially rooted in the lack of knowledge or appreciation of the significant impact that intrusive and extrusive volcanic rocks can have in interacting with the petroleum system. Additionally, exploration in Rockall is potentially at odds with normal dip closure driven exploration and workflows within other UKCS and global basins, as in the UK Rockall, these closures have potentially not been subject to efficient hydrocarbon migration and charge. It is therefore an interesting proposition that the lack of discovery of hydrocarbons within the UK Rockall may be the result of protracted hydrocarbon migration routes, rather than lack of viable source rocks, which is often cited as the main inhibitor to exploration within the basin.

\section{Acknowledgments}

We would like to acknowledge the two reviewers, Tony Dore and Clayton Grove for their constructive, positive and enthusiastic reviews which substantially improved this manuscript. The editor Matt Allen is thanked for encouragement and support in putting the paper together. We acknowledge a governmental research grant from the Oil and Gas Authority Frontier Basins Research Program and British Government for funding the project "Evaluating the Prospectivity of the Rockall Trough - Towards a Complete View of the Petroleum System West of Britain". Schofield would like to acknowledge the 8th Petroleum Geology of Northwest Europe Conference for the DG Roberts/Peter Zeigler Best Paper Award. This contribution forms part of the theme "Key Future Geoscience Challenges" held at the $8^{\text {th }}$ Petroleum Geology Conference. We would like to Acknowledge PGS for the donation of datasets in Rockall, and for continued support of research. CDA are acknowledged for providing publically released well and seismic data. Spectrum Geophysical are also thanked for donation of data for research in the Rockall. Interpretation was carried out using IHS Kingdom software. WGM 2012 gravity data courtesy of International Gravimetric Bureau. Maersk are thanked for use of Gravity Maps.

\section{References}

Archer, S. G., Bergman, S. C., lliffe, J., Murphy, C. M., and Thornton, M. (2005). Palaeogene igneous rocks reveal new insights into the geodynamic evolution and petroleum potential of the Rockall Trough, NE Atlantic Margin. Basin Research, I 7(I), I7I-20I. 
Clark, S.J., (2014) Constraining diagenetic timings, processes and reservoir quality in igneous-affected basins. Doctoral thesis, Durham University.

Cole, J. E., \& Peachey, J. (1999, January). Evidence for pre-Cretaceous rifting in the Rockall Trough: an analysis using quantitative plate tectonic modelling. In Geological Society, London, Petroleum Geology Conference series (Vol. 5, Pp. 359-370). Geological Society of London.

Doré, A. G., E. R. Lundin, C. Fichler, and O. Olesen. "Patterns of basement structure and reactivation along the NE Atlantic margin." Journal of the Geological Society I54, no. I (1997): 85-92.

Ebdon, C.C., Granger, P.J., Johnson, H.D., and Evans A.M., 1995. Early Tertiary evolution and stratigraphy of the Faeroe-Shetland Basin: Implications for hydrocarbon prospectivity. In: Scrutton R.A., et al. (eds) Sedimentation and palaeoceanography of the North Atlantic region, Geological Society of London, Special Publication 90: 5I-69

Ellis, D., \& Stoker, M. S. (20I4). The Faroe-Shetland Basin: A regional perspective from the Paleocene to the present day and its relationship to the opening of the North Atlantic Ocean. Geological Society, London, Special Publications, 397(I), I I-3I.

Emeleus, C. H., \& Bell, B. R. (2005). The Palaeogene volcanic districts of Scotland (Vol. 3). British Geological Survey.

Gray, J., Petroleum prospectivity of the principle sedimentary basins on the United Kingdom Continental Shelf, Deparment of Energy and Climate Change, available online: https://www.gov.uk/government/uploads/system/uploads/attachment_data/file/367282/UKCS _offshore_2013.pdf

Grove, C., (2014) Direct and Indirect Effects of Flood Basalt Volcanism on Reservoir Quality Sandstone. Doctoral thesis, Durham University.

Hallam, A. (1978). Eustatic cycles in the Jurassic. Palaeogeography, Palaeoclimatology, Palaeoecology, 23, I-32.

Hansen, D.M. and Cartwright, J., 2006. The three-dimensional geometry and growth of forced folds above saucer-shaped igneous sills. Journal of Structural Geology, 28(8), Pp. I520-I535

Helland-Hansen, D. 2009: Rosebank - challenges to development from a subsurface perspective. In: Varming, T. \& Ziska, H. (eds): Faroe Islands Exploration Conference: Proceedings of the 2nd Conference. Annales, London, Special, Publications, I0I, 63-78.

Hitchen, K., Johnson, H. \& Gatliff, R. W. (eds) 20I3, Geology of the Rockall Basin and Adjacent Areas. British Geological Survey, London, Research Report RR/I2/03, 96- 136 
Holford, S. P., Green, P. F., Hillis, R. R., Underhill, J. R., Stoker, M. S., and Duddy, I. R. (20I0). Multiple post-Caledonian exhumation episodes across NW Scotland revealed by apatite fission-track analysis. Journal of the Geological Society, 167(4), 675-694.

Holford, S., Schofield, N., MacDonald, J., Duddy, I., and Green, P. (20I2). Seismic analysis of igneous systems in sedimentary basins and their impacts on hydrocarbon prospectivity: examples from the southern Australian margin.

Iliffe, J.E., Robertson, A.G., Ward, G.H.F., Wynn, C., Pead, S.D.M. \& Cameron, N. 1999. The importance of fluid pressures and migration to the hydrocarbon prospectivity of the FaroeShetland White Zone. In: Fleet, A.J. \& Boldy, S.A.R. (eds) Petroleum Geology of Northwest Europe: Proceedings of the 5th Conference. Geological Society, London, 60I-6II.

Jones, D. W., \& Underhill, J. R. (20II). Structural and stratigraphic evolution of the Connemara discovery, Northern Porcupine Basin: significance for basin development and petroleum prospectivity along the Irish Atlantic Margin. Petroleum Geoscience, I 7(4), 365-384.

Kheidri, L. H., Cailly, F., Jones, K., De Senneville, A., \& Gray, R. (20I4). Laggan Field 3D geological modelling: case study. Geological Society, London, Special Publications, 397(I), I07-I2I.

Magee, C., Jackson, C. L., and Schofield, N. (20I4). Diachronous sub-volcanic intrusion along deepwater margins: insights from the Irish Rockall Basin. Basin Research, 26(I), 85-I05.

Millett, JM., Hole, MJ., Jolley, DW., Schofield, N. \& Campbell, E. (2016). 'Frontier exploration and the North Atlantic Igneous Province: new insights from a $2.6 \mathrm{~km}$ offshore volcanic sequence in the NE Faroe-Shetland Basin'. Journal of the Geological Society, vol I73, no. 2, Pp. 320-336.

Morton, N. (1992). Dynamic stratigraphy of the Triassic and Jurassic of the Hebrides Basin, NW Scotland. Geological Society, London, Special Publications, 62(1), 97-II0.

Musgrove, F. W., \& Mitchener, B. (1996). Analysis of the pre-Tertiary rifting history of the Rockall Trough. Petroleum Geoscience, 2(4), 353-360.

Nadin, P. A., Houchen, M. A., \& Kusznir, N. J. (1999, January). Evidence for pre-Cretaceous rifting in the Rockall Trough: an analysis using quantitative 2D structural/stratigraphic modelling. In Geological Society, London, Petroleum Geology Conference series (Vol. 5, Pp. 37I-378). Geological Society of London.

Passey, S.R., and Jolley, D.W., 2009, A revised lithostratigraphic nomenclature for the Palaeogene Faroe Islands Basalt Group, NE Atlantic Ocean: Earth and Environmental Science Transactions of the Royal Society of Edinburgh, v. 99, p. I27-I58. 
Ramm, M., \& Bjørlykke, K. (1994). Porosity/depth trends in reservoir sandstones: Assessing the quantitative effects of varying pore-pressure, temperature history and mineralogy, Norwegian Shelf data. Clay minerals, 29(4), 475-490.

Rateau, R., Schofield, N., and Smith, M. (2013). The potential role of igneous intrusions on hydrocarbon migration, West of Shetland. Petroleum Geoscience, 19(3), 259-272.

Rawcliffe, H.J., (20I6) ava-water-sediment interaction: processes, products and petroleum systems. PhD thesis, University of Glasgow.

Scotchman, I.C., Carr, A.D., and Parnell, J., 2006, Hydrocarbon generation modelling in a multiple rifted and volcanic basin: A case study in the Foinaven Sub-basin, Faroe-Shetland Basin, UK Atlantic margin: Scottish Journal of Geology, v. 42, no. I, p. I-19.

Schofield, N., and Jolley, D.W (2013) - Development of Intra-Basaltic Lava Field Drainage Systems within the Faroe-Shetland Basin, Petroleum Geoscience, Vol. 19, pp. 259-272

Schofield, N., Holford, S., Millett, J., Brown, D., Jolley, D., R. Passey, S., Muirhead, D., Grove, C., Magee, C., Murray, J., Hole, M., A.-L. Jackson, C. and Stevenson, C. (20I5), Regional magma plumbing and emplacement mechanisms of the Faroe-Shetland Sill Complex: implications for magma transport and petroleum systems within sedimentary basins. Basin Res. doi:|0.| | | |/bre. 12164

Shannon, P., \& Naylor, D. (2010). Petroleum Geology of Ireland. Dunedin Academic Press.

Stein, A.M. and Blundell, D.J., 1990. Geological inheritance and crustal dynamics of the northwest Scottish Continental Shelf, Tectonophysics, 173, 455-467.

Štolfová, K., \& Shannon, P. M. (2009). Permo-Triassic development from Ireland to Norway: basin architecture and regional controls. Geological Journal, 44(6), 652-676.

Watton, T., (20I3) A MULTIDISCIPLINARY ASSESSMENT OF HYALOCLASTITE DEPOSITS IN PETROLEUM SYSTEMS USING FIELD STUDIES, DRILL CORE, BOREHOLE IMAGE AND WIRELINE LOG DATASETS. Doctoral thesis, Durham University.

Wright, K. A., R. J. Davies, D. A. Jerram, J. Morris and R. Fletcher 20I2. Application of seismic and sequence stratigraphic concepts to a lava-fed delta system in the Faroe-Shetland Basin, UK and Faroes. Basin Research, Volume 24, Issue I, pages 91-106, February 2012

Fig. I - GEBCO bathymetry map of the UK Continental Shelf (UKCS) and NE Atlantic Margin. Coordinate Reference System - UTM Zone 29, ED50 datum. 
Fig. 2 A) Free Air gravity anomaly map of the NW seaboard of the UKCS and eastern flank of Rockall, showing main basin, structural highs and and igneous centres B) Free Air gravity anomaly map of the NW seaboard of the UKCS and eastern flank of Rockall, showing all exploration wells drilled within the basin. A total of only 12 exploration wells have been drilled in Rockall since 1980.

Fig. 3 - Schematic map showing shelf and intra-shelf basins, igneous centres and the continent-ocean boundary $(\mathrm{COB})$ in relation to Rockall.

Fig. 4 - Palaeogene and Cretaceous stratigraphy on Atlantic Margin (modified from Schofield and Jolley, 2013), with British Geological Survey lithostratigraphy (Ritchie et al. 20II), BP T-sequence framework (after Ebdon et al. 1995), stratigraphical position of the Faroe Island Basalt Group (FIBG) (after Passey and Jolley 2009) and major igneous events along Scotland's west coast (after Emeleus and Bell, 2005)

Fig. 5 Figure showing regional well correlations of Palaeogene volcanic and Colsay Fm. sequences from the Faroes and Faroe-Sheltand Basin A) Location map of wells B) Volcanic edifice (sequence T40 (Flett Fm.) in age) located next to George Bligh Igneous Centre (see Fig. 2). OGA seismic line 0006IA236 C) Correlation of the Faroe-Island Basalt Group (FIBG) with extrusive volcanic sequences in NE Rockall. Extrusive sequences penetrated within I54/3-I and 164/25-2 in the UK Rockall were erupted during sequence T40 (Flett Fm.) and are equivalent to the lower sequences of the FIBG (Beinisvørठ Fm.). Importantly, the wells do not record any sequence T45 volcanics, implying that as volcanism continued in the region of the Faroes and FSB, extrusive volcanism had largely ceased on Rockall's eastern flank. D) Correlation of Rosebank well 2/3/27-2, drilled on the Corona Ridge (FSB) too I54/3-I and 164/25-2 in NE Rockall. Colsay Mbr. equivalent interbeds can be picked up in both I54/3-I and 164/25-2, were the Colsay Mbr. equivalent sequence is composed of approx. I50m of porous clastic material in well 164/25-2.

Fig. 6 Figure showing timeline of exploration within the UK Rockall, up to currently the last well drilled in the basin in 2006 
Fig. 7 Figure showing seismic and geoseismic interpretations of some key exploration wells within the NE Rockall. A) 165/25-Iz drilled by BP in 1988, note the underlying sill and truncation of strata against the Top Balder marker B) Seismic line across the Antaeus closure targeted by well 164/27-I. Note the highly pervasive underlying sill complex underlying the closure C) Benebecula South Discovery (I54/I-I) and Benbecula North (I54/I-2), again note the underlying sill complex beneath the closures.

Fig. 8 Figure showing seismic and geoseismic interpretation through the southern portion of the UK Rockall and wells I32/6-I and I32/I5-I drilled in 199I and 200I respectively. The line intersects the southern extent of the Anton Dohrn igneous centre (see Fig. I). It is interesting to note that well $132 / 6-1$ also targets a closure, which is underlain by a series of sills (see text for details). OGA seismic line AMWGI4-022.

Fig. 9 Figure showing seismic and geoseismic interpretation through well 164/25-2 drilled by BP in 1990 and well 164/7-I drilled by Conoco in 1997. Well 164/25-2 penetrated 150m of Sequence T40 (Flett Fm) Colsay member sandstone equivalent clastic material. The sequence can be seen thinning towards the Outer Hebrides Shelf. Westwards, away from the West Lewis Ridge into the NE Rockall basin the sequences appears to thicken, before likely becoming inter-fingered with time equivalent extrusive volcanic sequences that were penetrated within I64/7-I.

Fig. IO A) TWT map of near Top Vaila Fm. within the NE Rockall. The broad closure of the Benbecula South discovery (I54/I-I) can be seen. Benbecula North (I54/I-2) can be seen to have targeted a sub-closure within the larger Benbecula structure, but was found on drilling to be dry. Well I64/27-I and 164/28-I A have less well defined closures in the Top Vaila Fm. B) Oblique view looking south showing TWT map in figure A.

Fig. II Figure showing seismic and geoseismic interpretation through Benbecula South discovery $(154 / I-I)$. The Benbecula structure is underlain by a series of saucer-shaped 
intrusions. The eastern flank of the intrusions can be seen climbing subvertically (potentially up an un-imaged fault plane) and intersecting with the Vaila Fm. reservoir unit penetrated by Benbecula. This intrusion may have acted as a potential charging route (see Schofield et al. $2015)$ to the Benbecula reservoir sands. Potential also exists for hydrocarbons charging units up-dip towards the east and Outer Hebrides Shelf.

Fig. I2 A) and B) Figure showing seismic and geoseismic interpretation though well 164/28IA which encountered oil shows within the Vaila Fm. sequences. Well I64/28-IA was drilled to the west of a transgressive sill, which appears to cut up into the $\sim 300 \mathrm{~m}$ thick Vaila Fm. sandstone sequence penetrated by Well I64/28-IA that contained oil shows, and has a NTG of >> 0.5 C) and D) The subsurface scenario seen in the vicinity of I64/28-IA (Fig. D) closely matches that seen in relation the Tormore field in the Faroe-Shetland Basin (Fig. C), which it has been suggested was charged via hydrocarbons exploiting a fractured pathway through the intrusion which impacts very close to the down-dip extent of the of the Tormore reservoir sand body (Schofield et al. 20I5). If this same scenario was operating in relation to the vicinity of 164/28-IA, the transgressive sill may have baffled hydrocarbons into the Vaila Fm. sandstone sequence away from I64/28-IA and potentially into a stratigraphic trap up-dip from the 164/28-IA well location, with the overlying Hyaloclastite sequence acting as a possible seal E) Schematic modified from Rateau et al. 2013, showing potential creation of shadow zones in relation to hydrocarbon migration and intrusions.

Fig. I3 A) Figure showing comparison of depth and porosity relationship of Vaila Fm. sandstone reservoirs along the Atlantic Margin. Due to the lack of presence of Chlorite overgrowths, porosity of Benbecula was around 19\%

Fig 14 - Figure showing that the Benbecula reservoirs sits within a trend of possessing lower then expected porosity for depth, as a result of carbonate sedimentation. Porosity depth trend line from Ramm and Bjørlykke (1994) 
Fig. I5 A) Free-Air Gravity anomaly map showing location of Benbecula discovery in relation to the Rosemary Bank and Darwin Igneous Centres. B) Seismic line from Benbecula to Rosemary bank. Despite the degradation in imaging, the shear areal extent of the Rosemary Bank Igneous centre is clear, with it being approximately four times larger in areal extent then the Cuillin Centre on Skye. Seismic data was originally acquired by Total and Statoil has been accessed from public archives through the CDA portal C) Palaeotemperature profile through Benbecula discovery showing high temperatures of up to $240^{\circ} \mathrm{C}$ that were experienced within the Vaila $\mathrm{Fm}$. sandstone reservoir and interpreted as a result of hot fluids moving through the reservoir sequence (from Geotrack report \#74 OGA public well release), originating either from the underlying and adjacent sills, and/or as part of a larger hydrothermal circulatory system set up within the NE Rockall Basin by heating effects of the Rosemary Bank and Darwin Igneous Centres.

Fig. I6 Figure showing a schematic map of the potential play fairway of Colsay member sandstone play along Rockall's eastern flank (see text for details). Base map after Hitchen et al. (2013) 



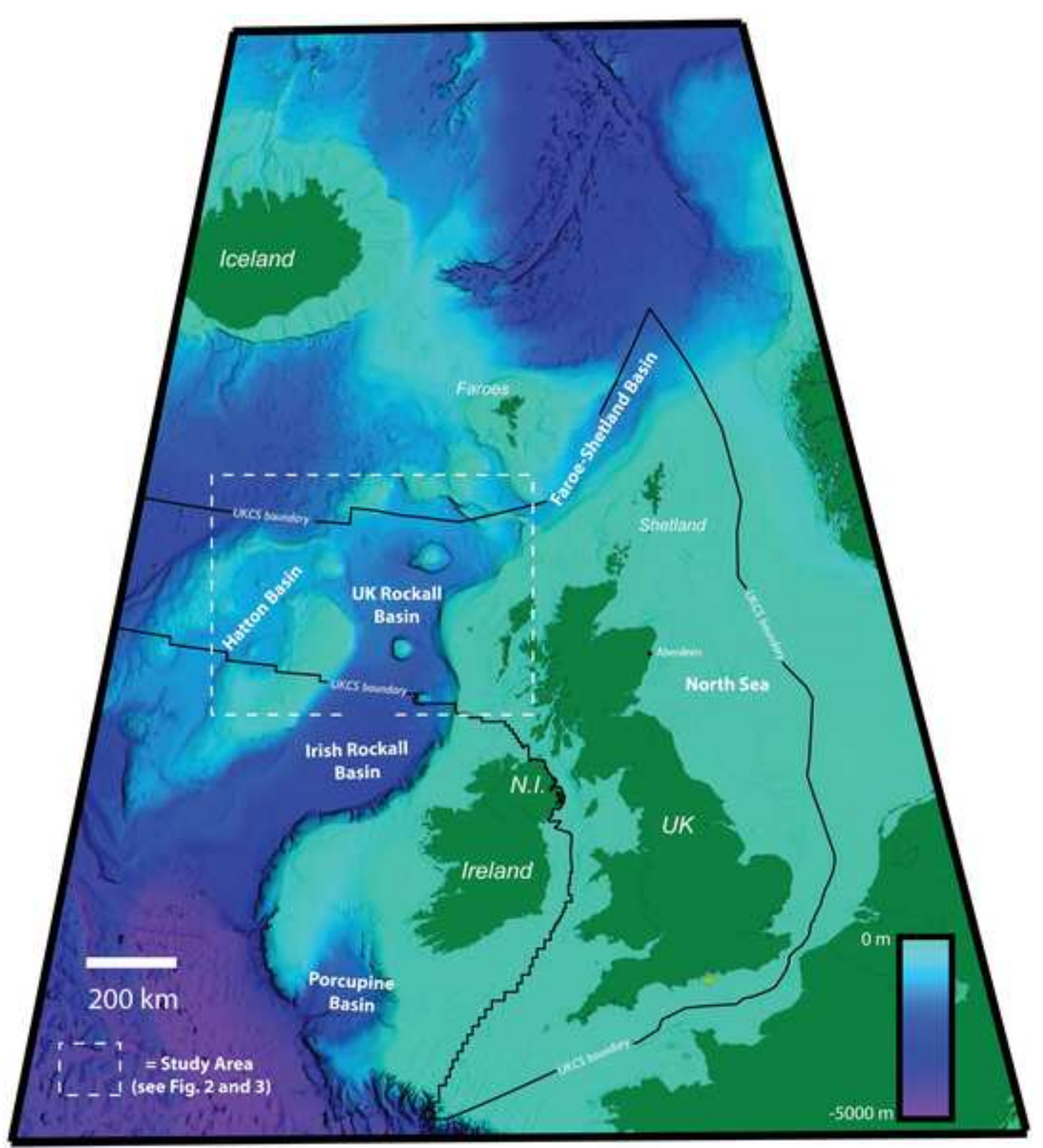



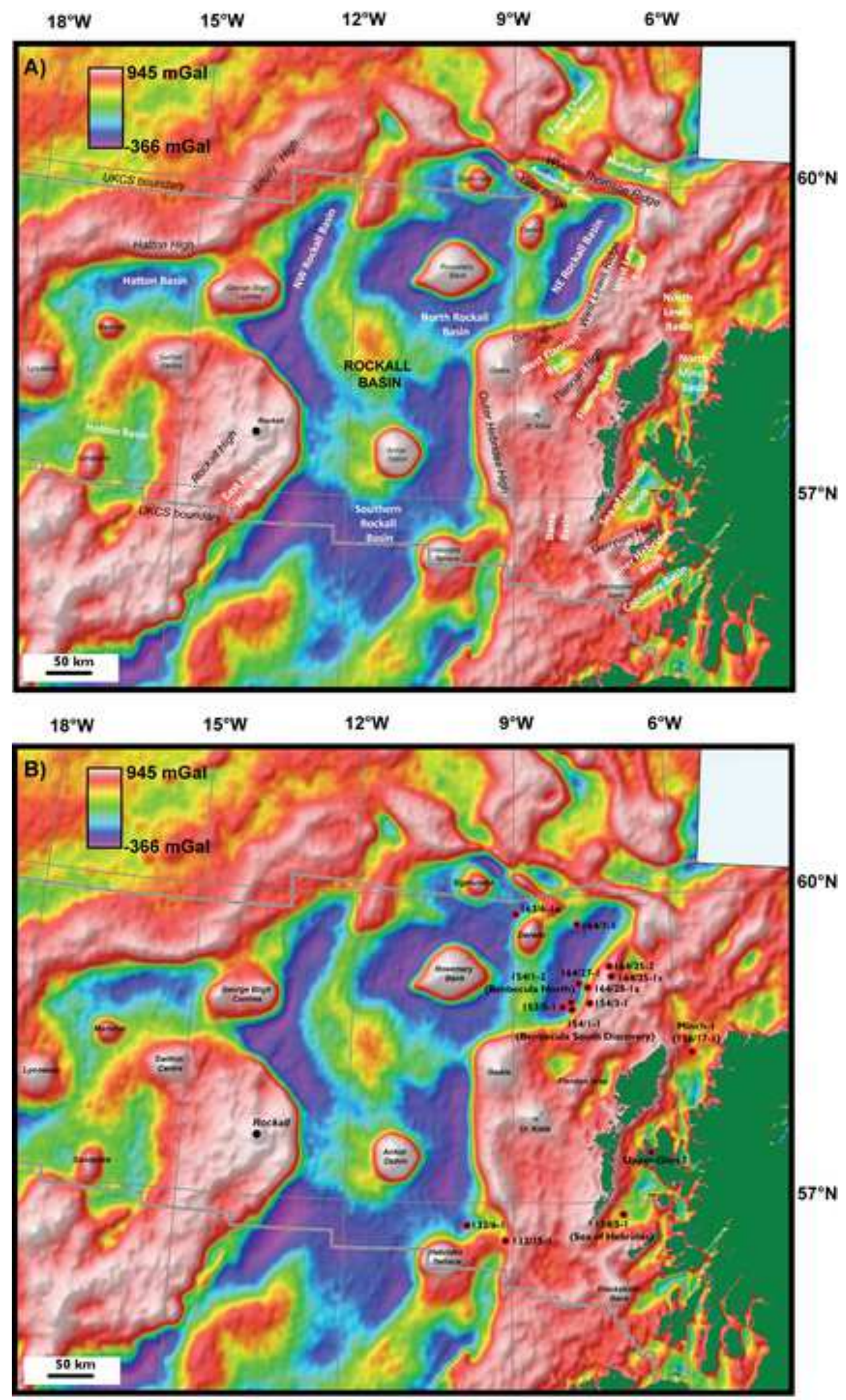


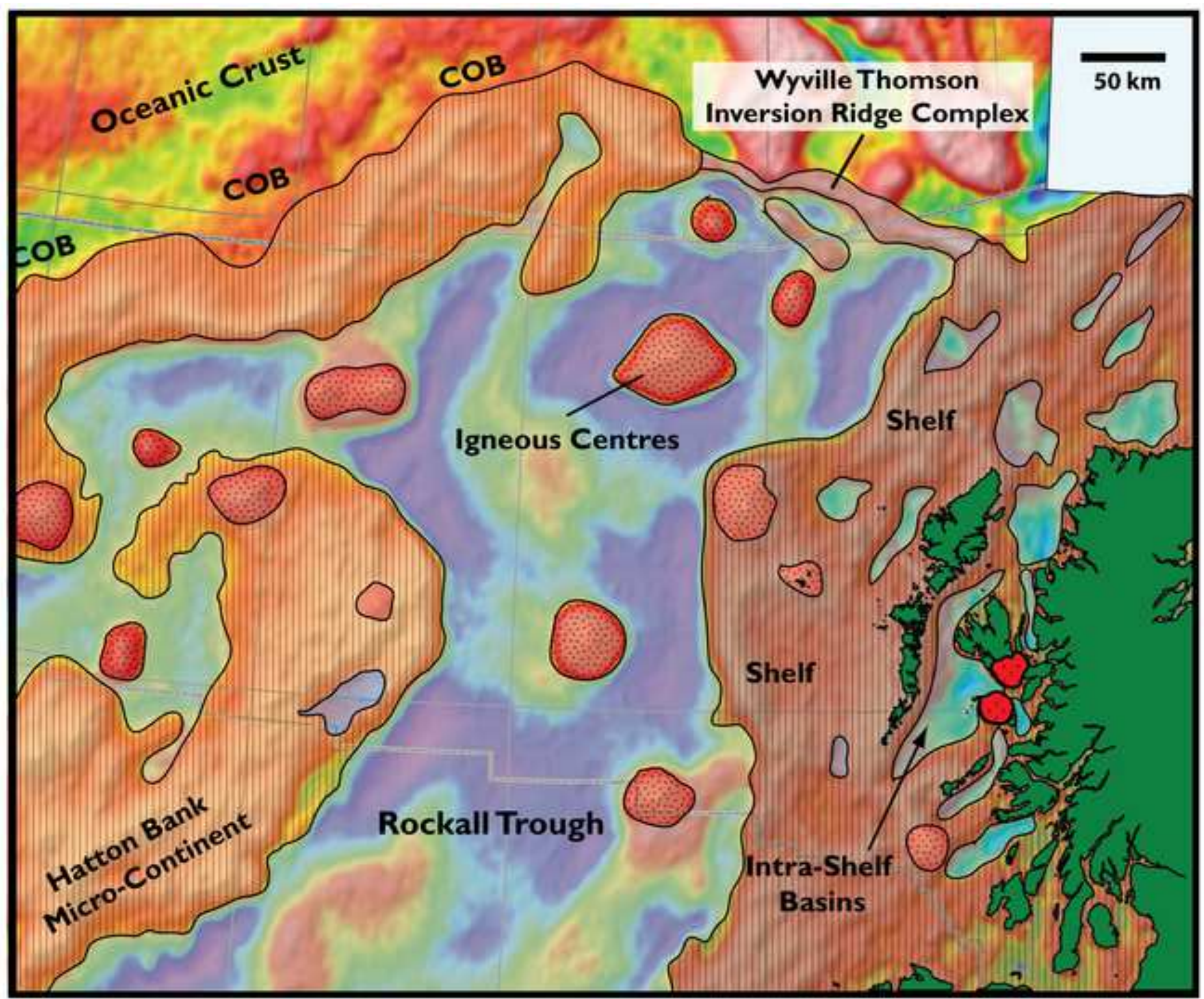




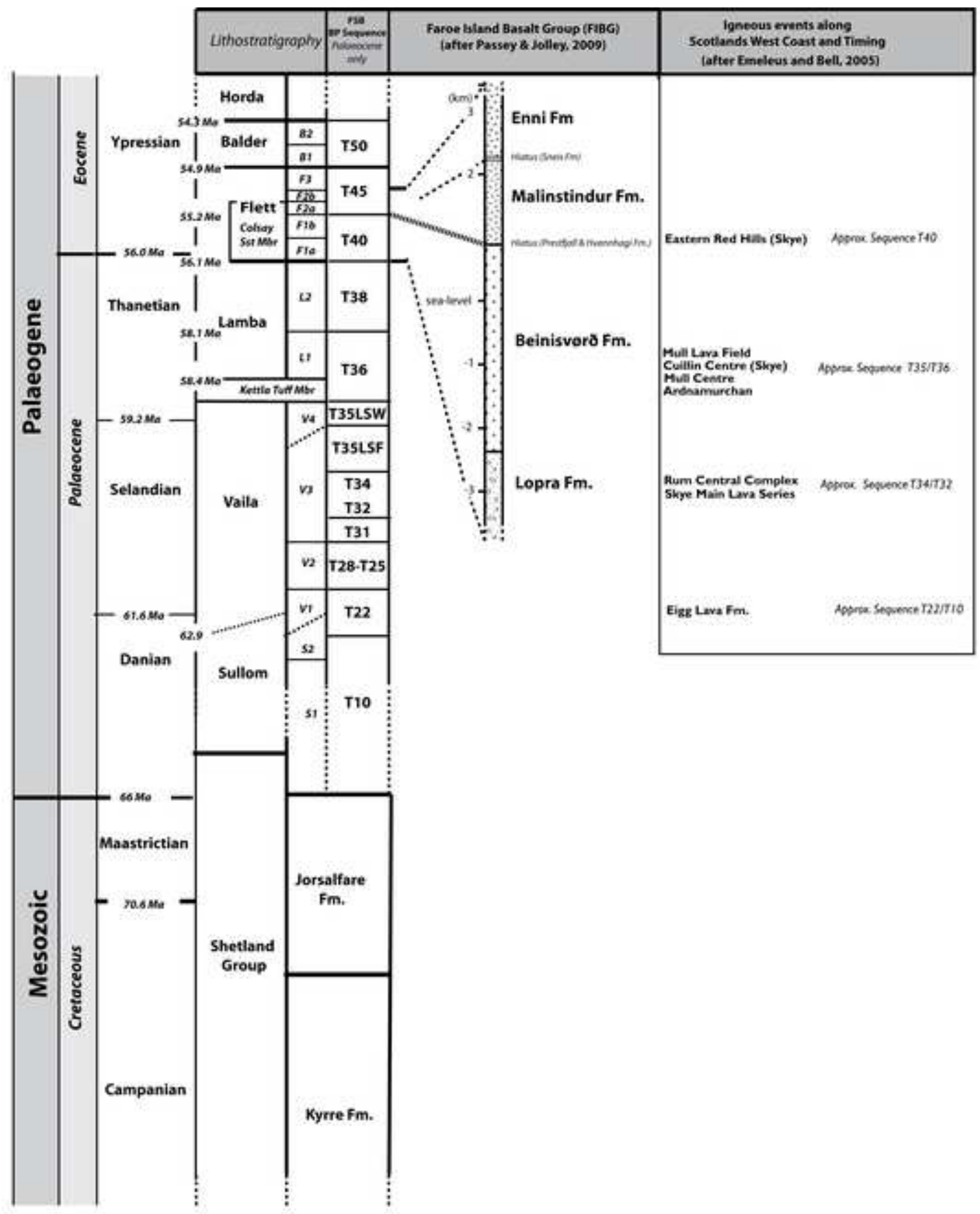



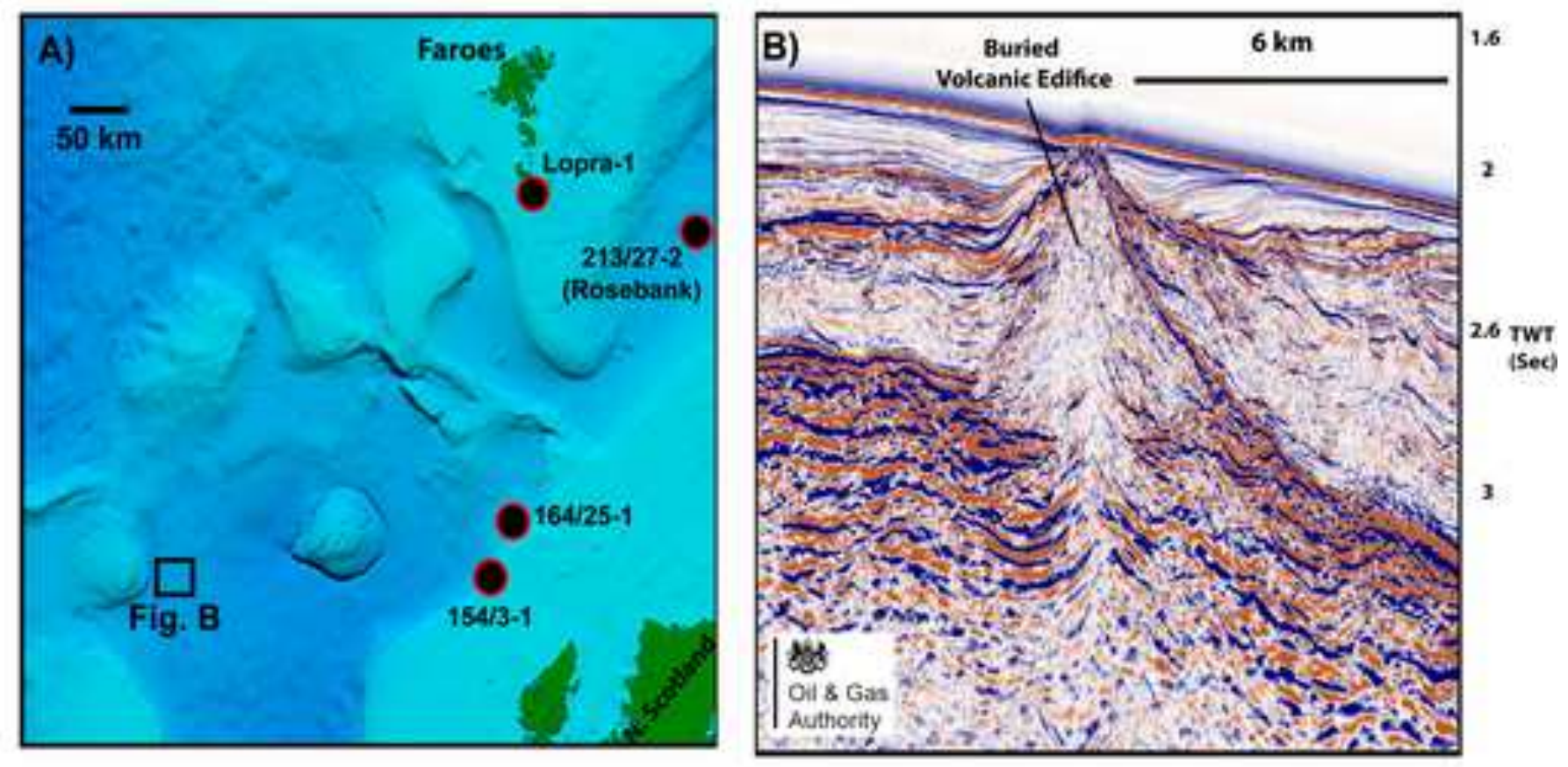

C)

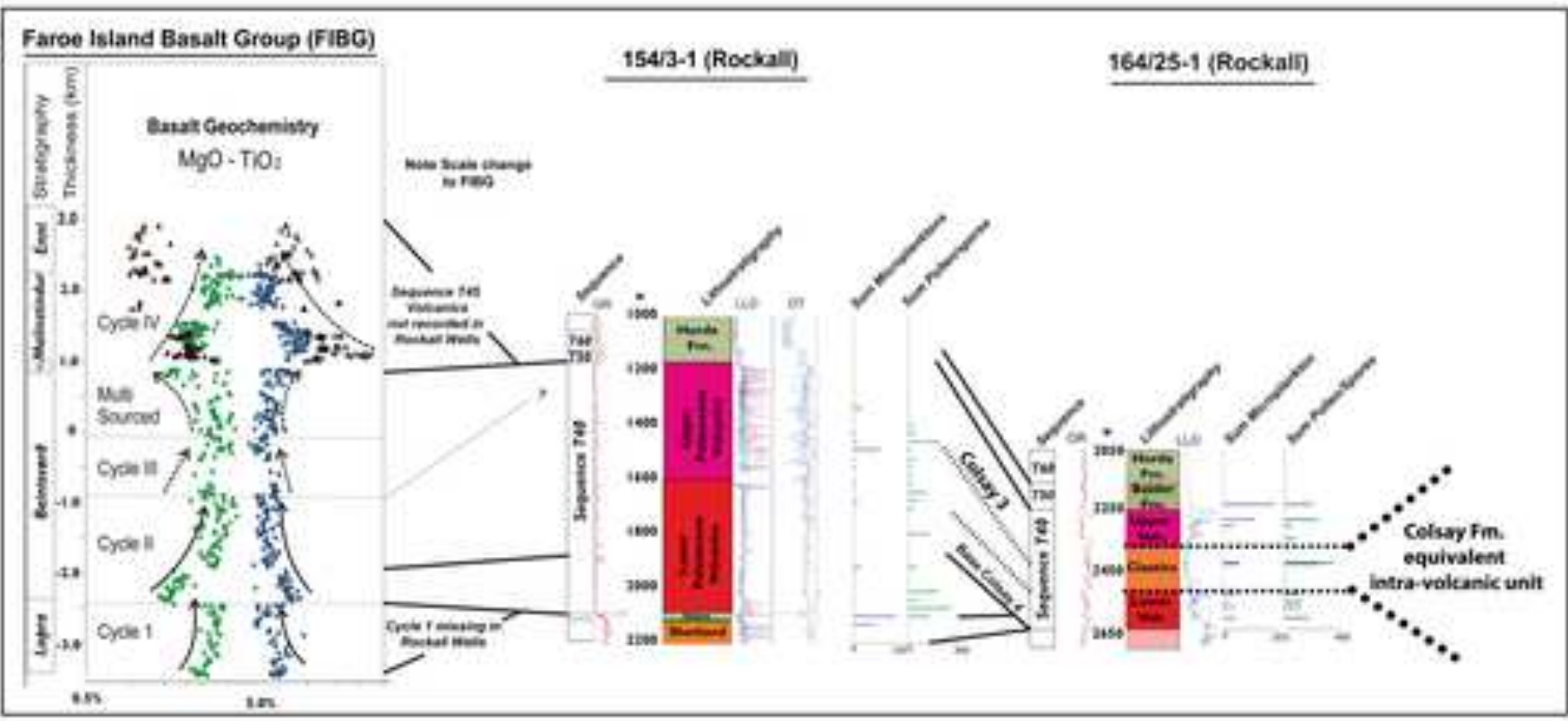

D)
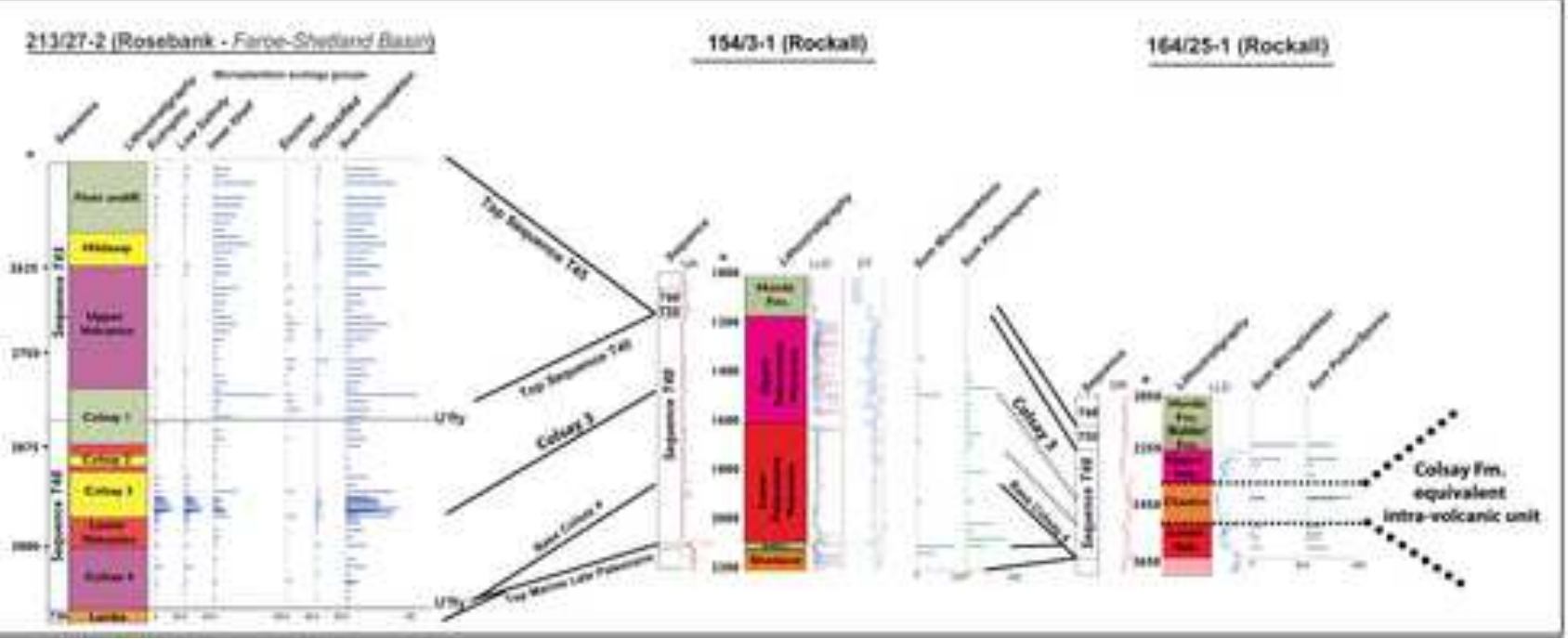


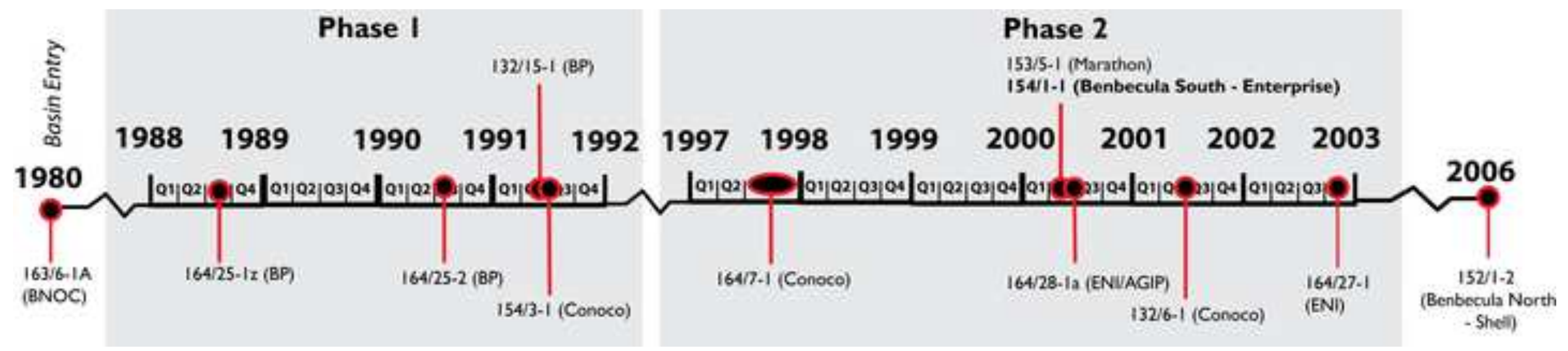




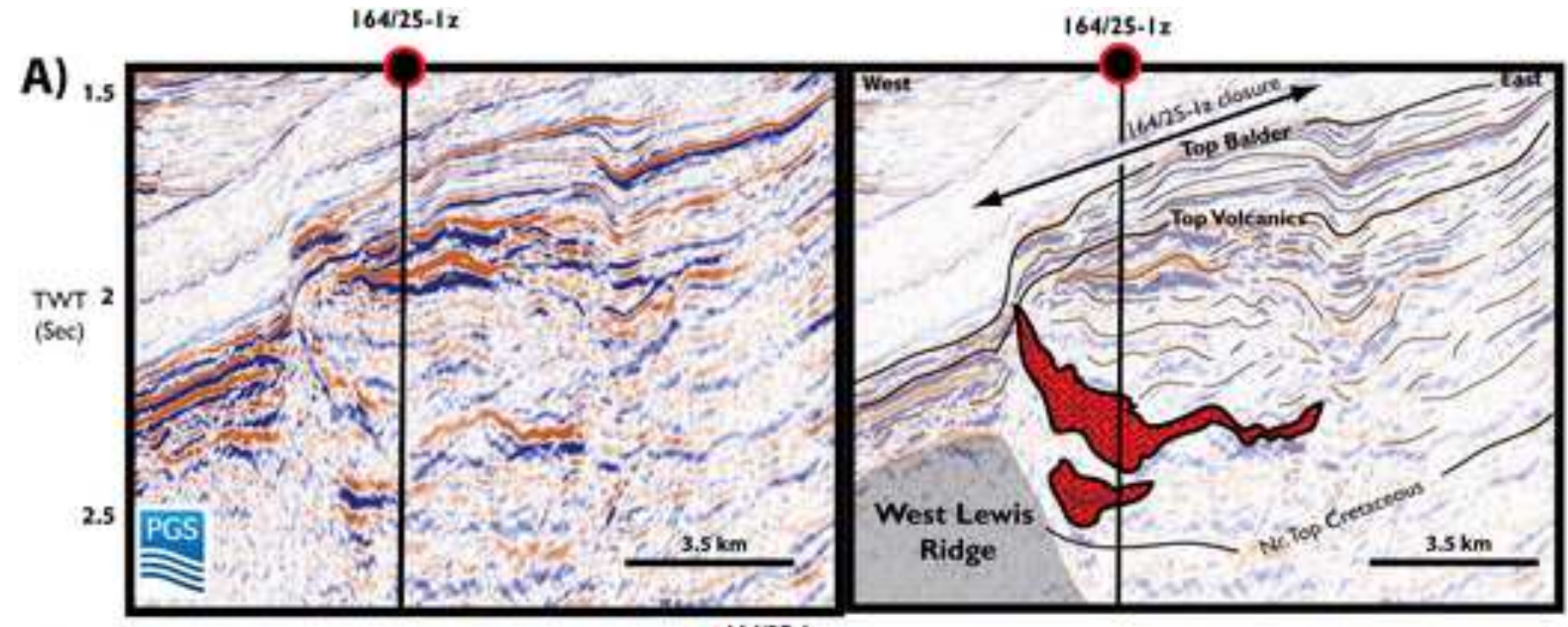

B)

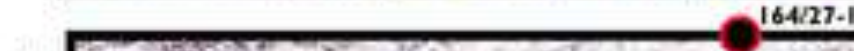

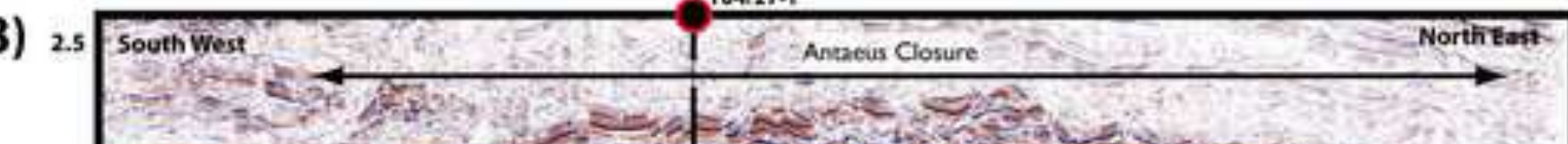
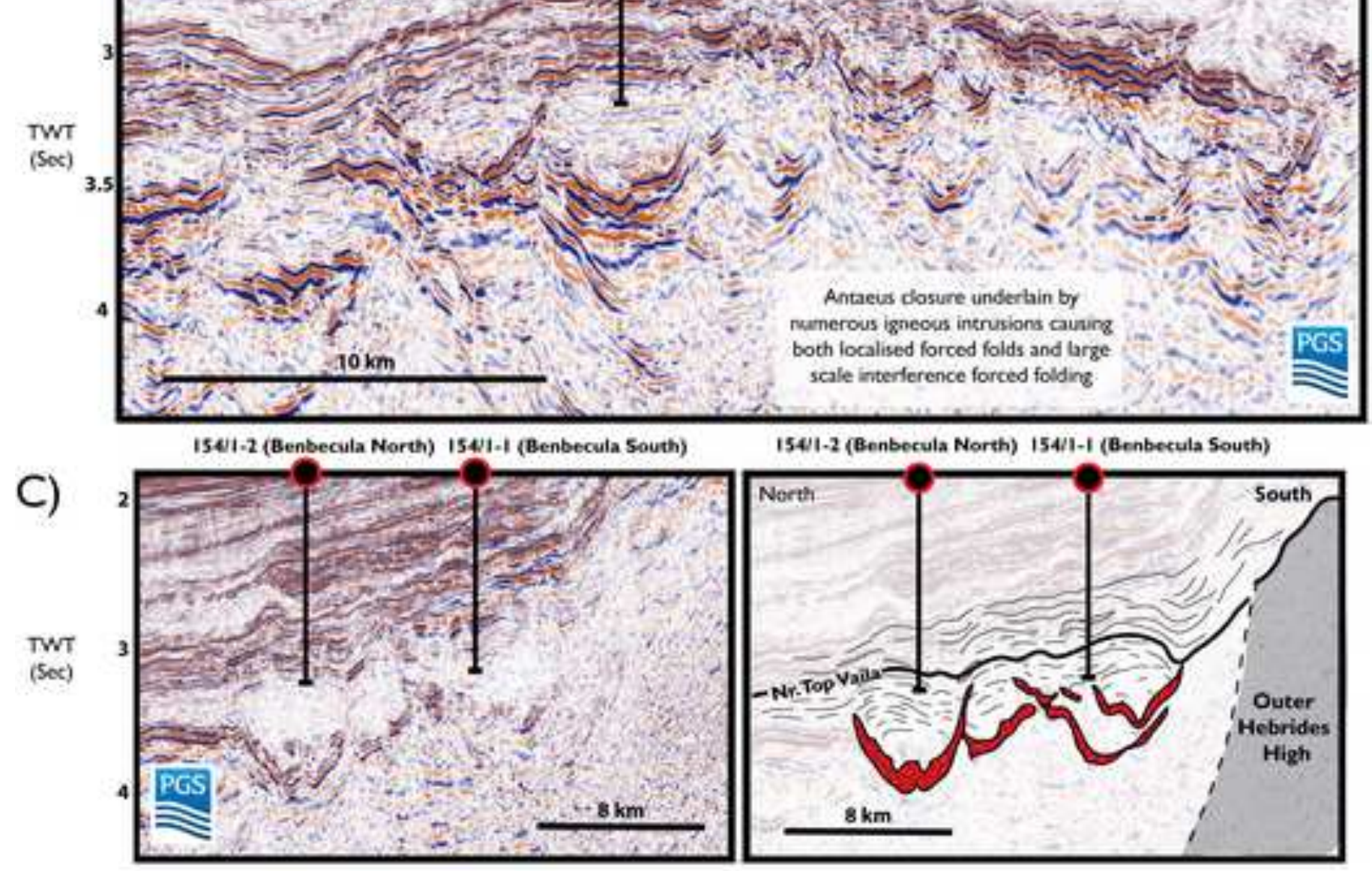

154/1-2 (Benbecula North) 154/1-1 (Benbecula South)

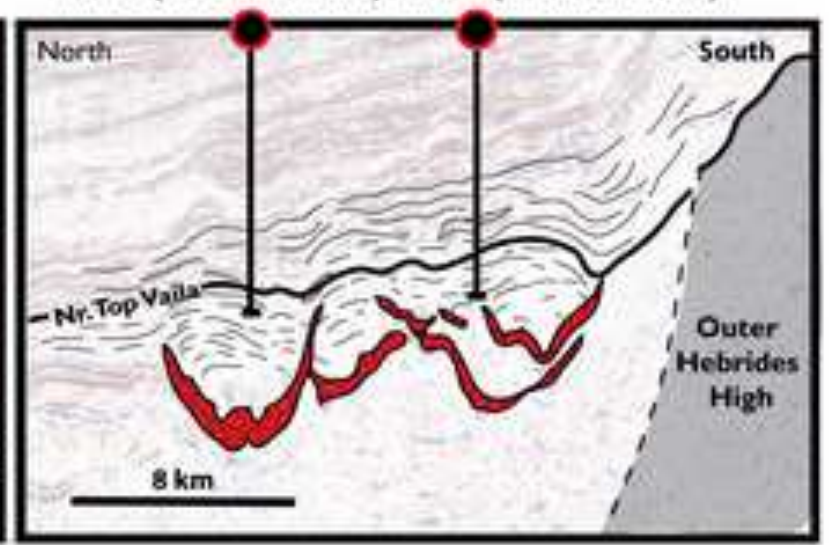



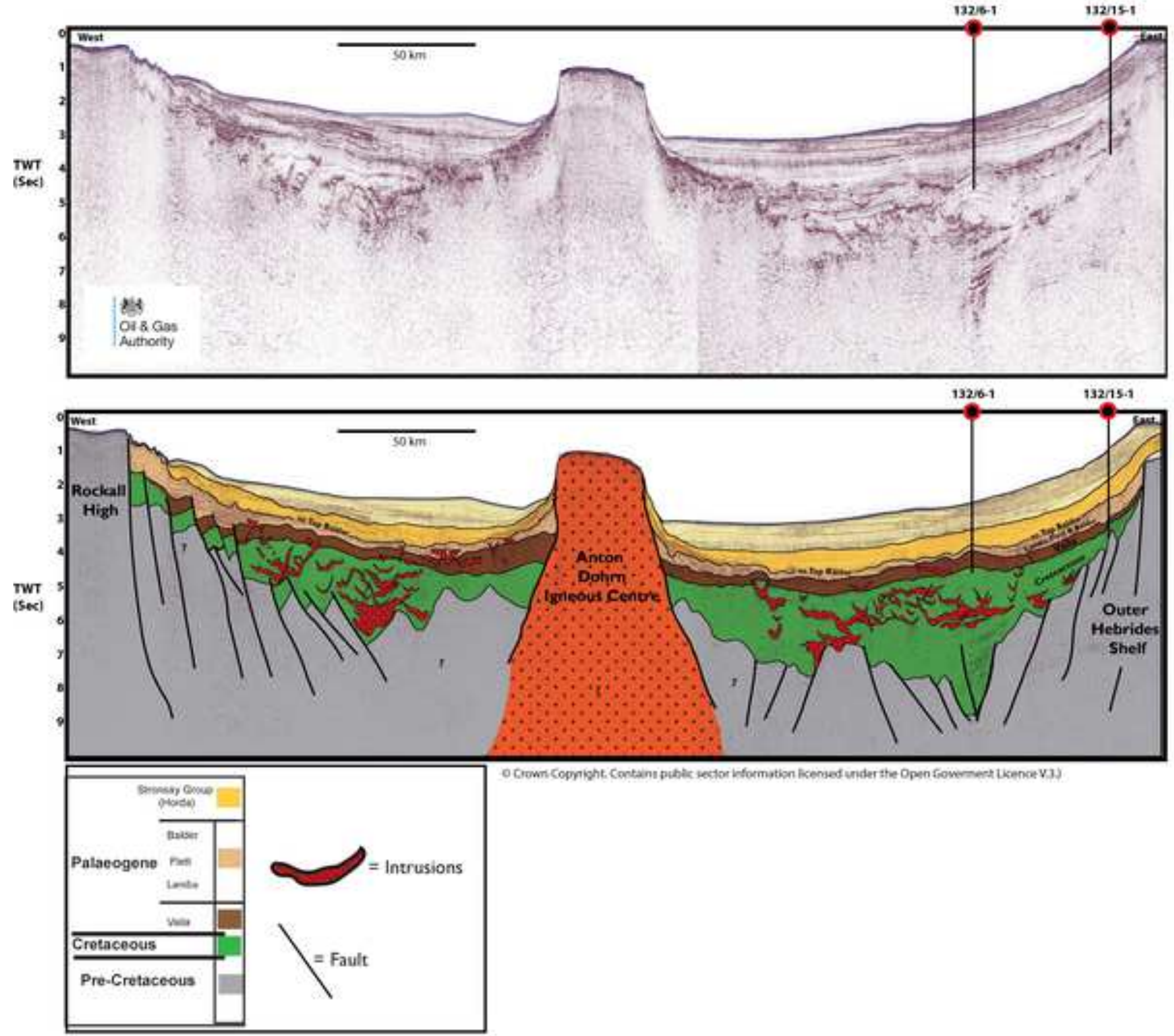

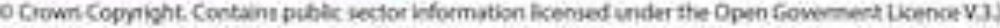




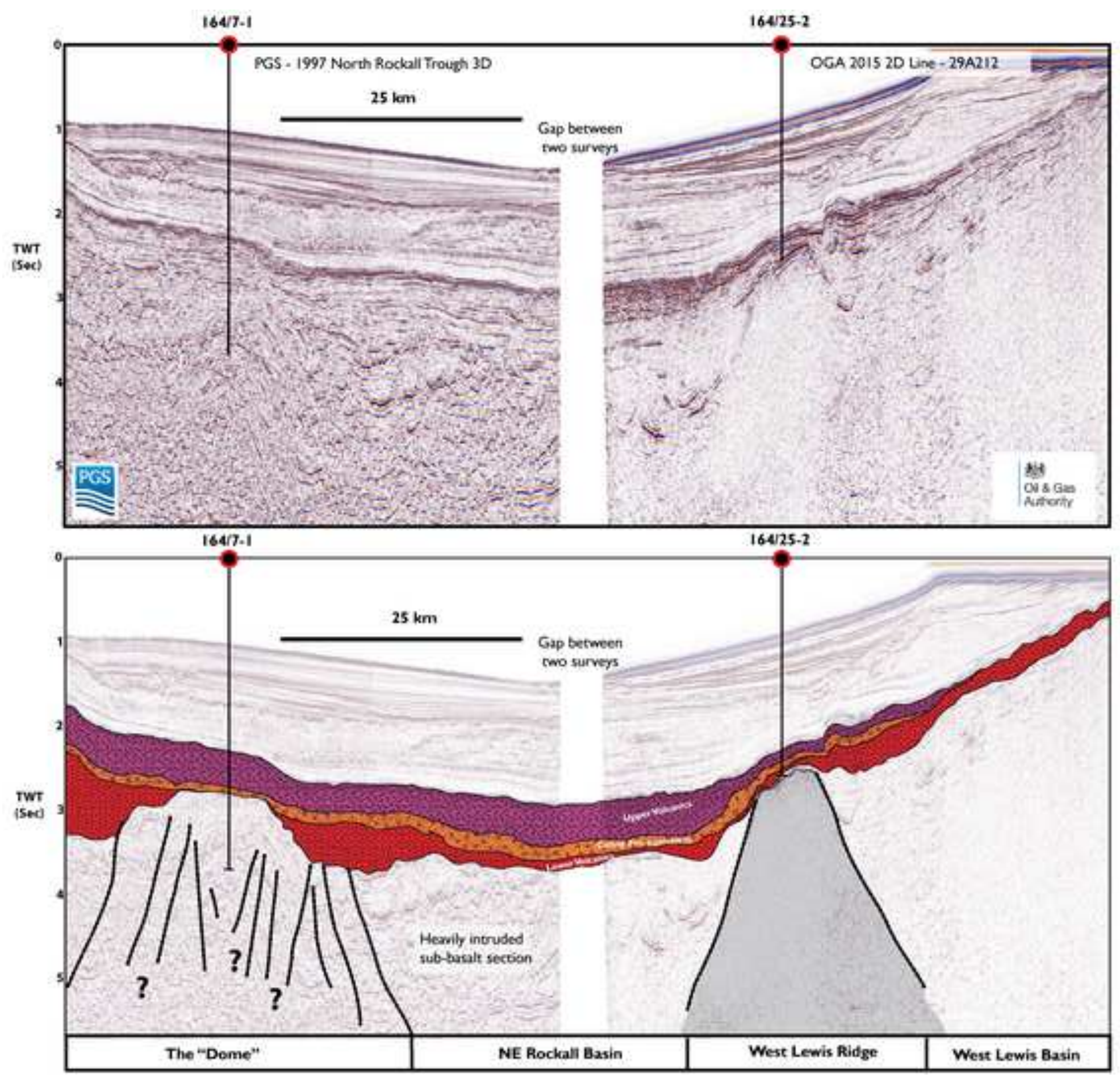




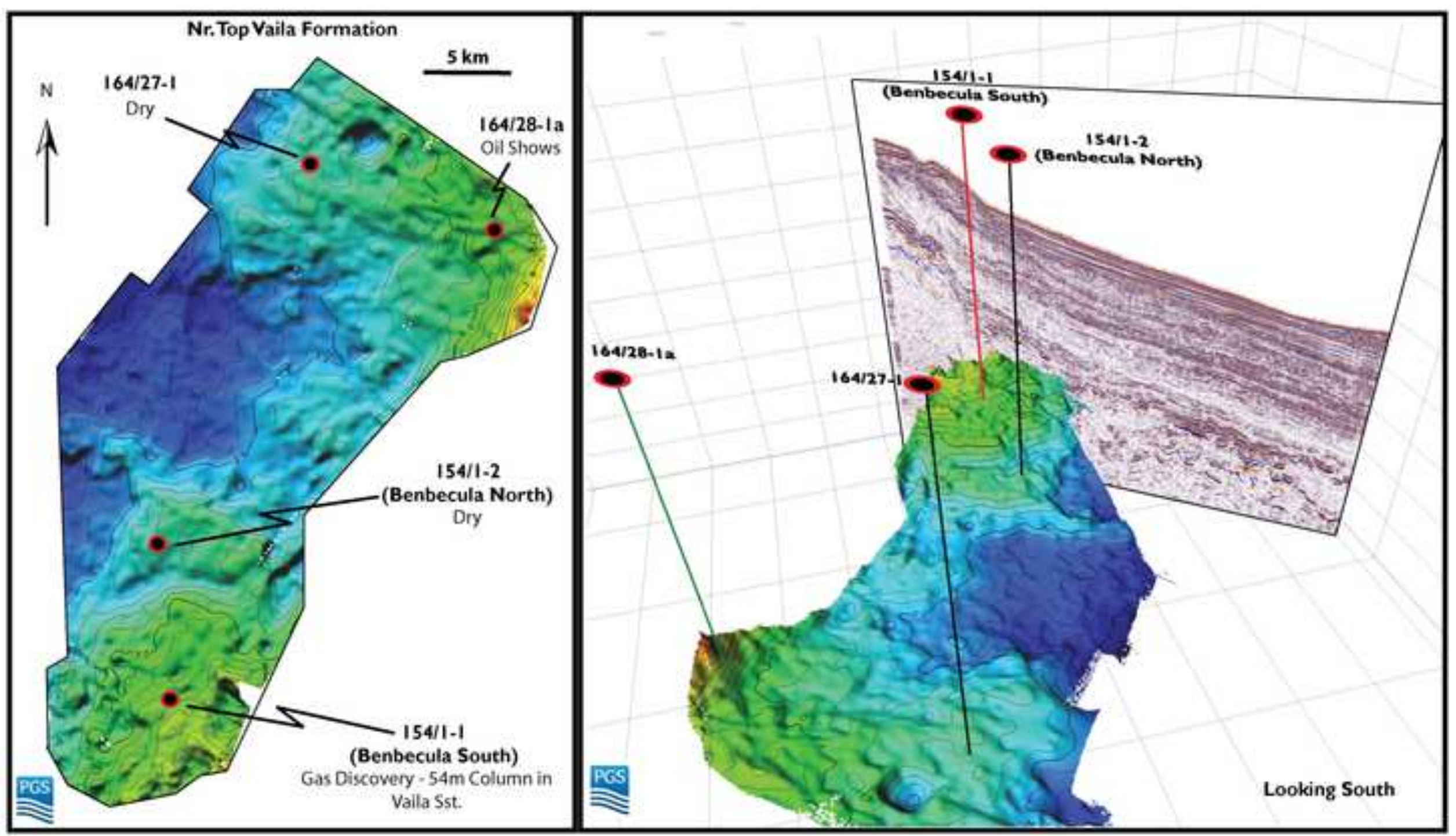


154/1-1 (Benbecula South)
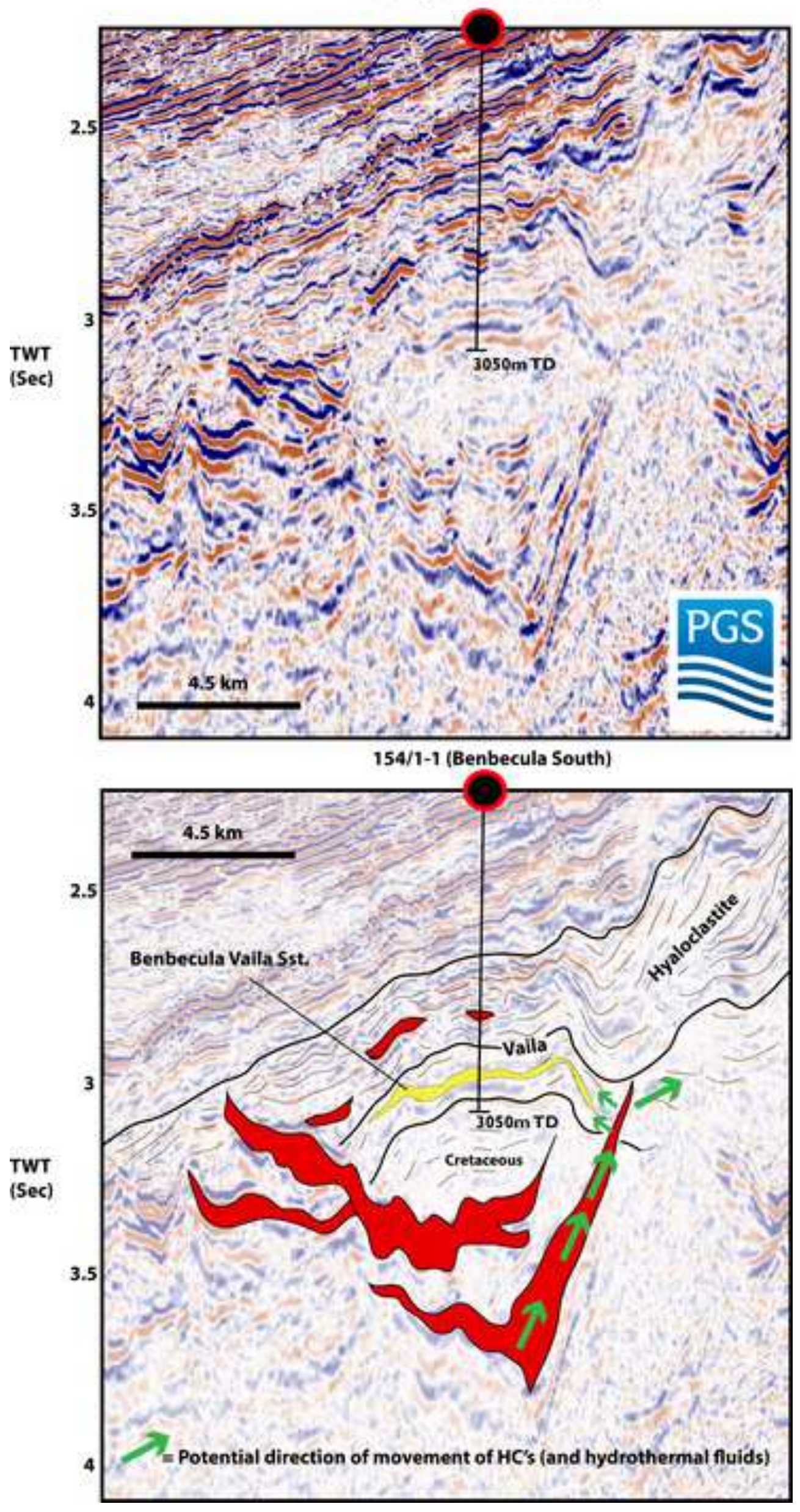

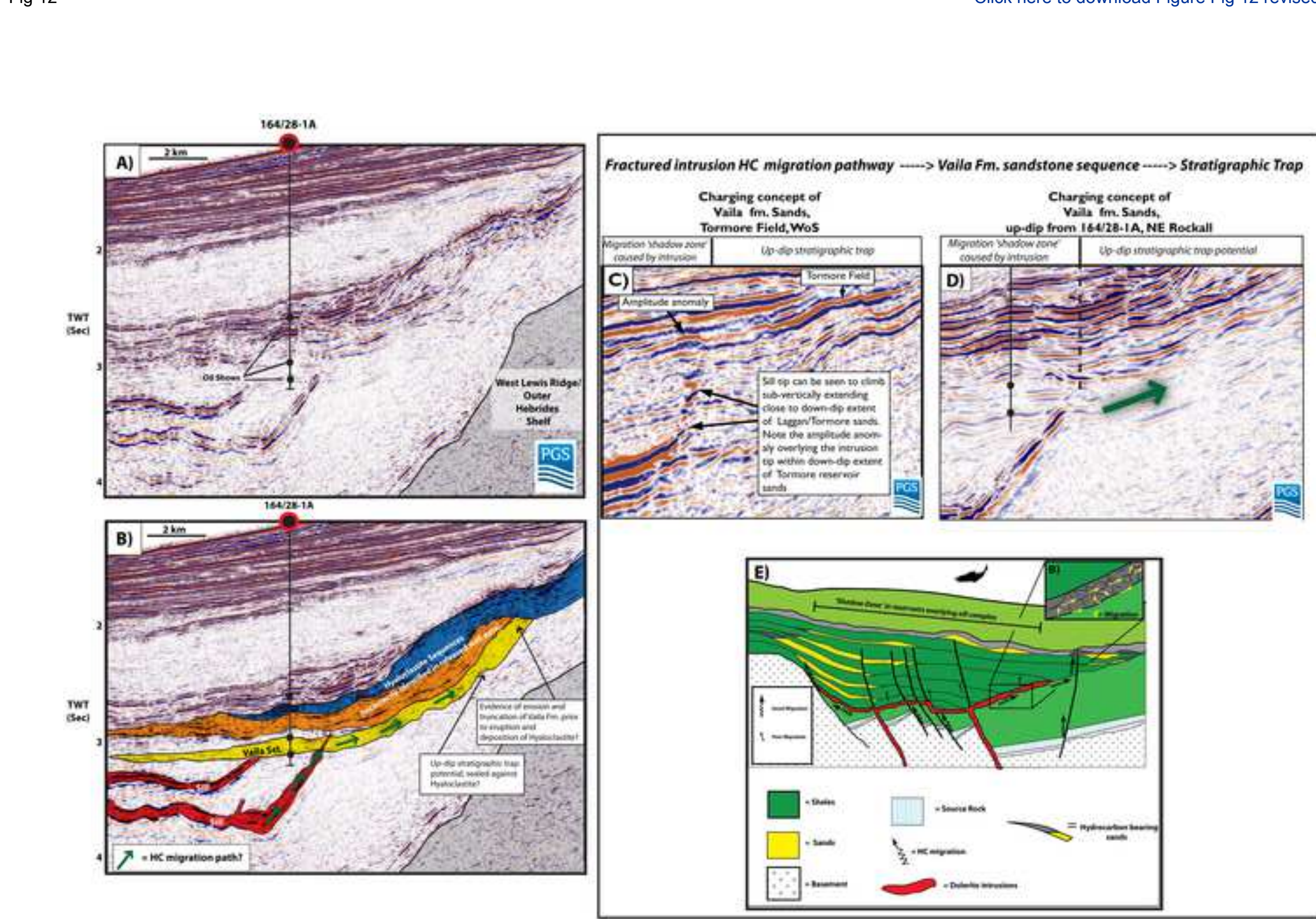

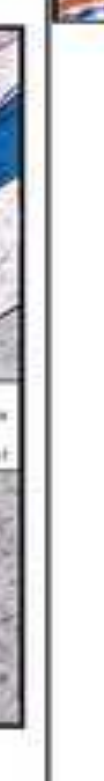




\section{Well Depth Porosity \\ Petrography schematic \\ Core}

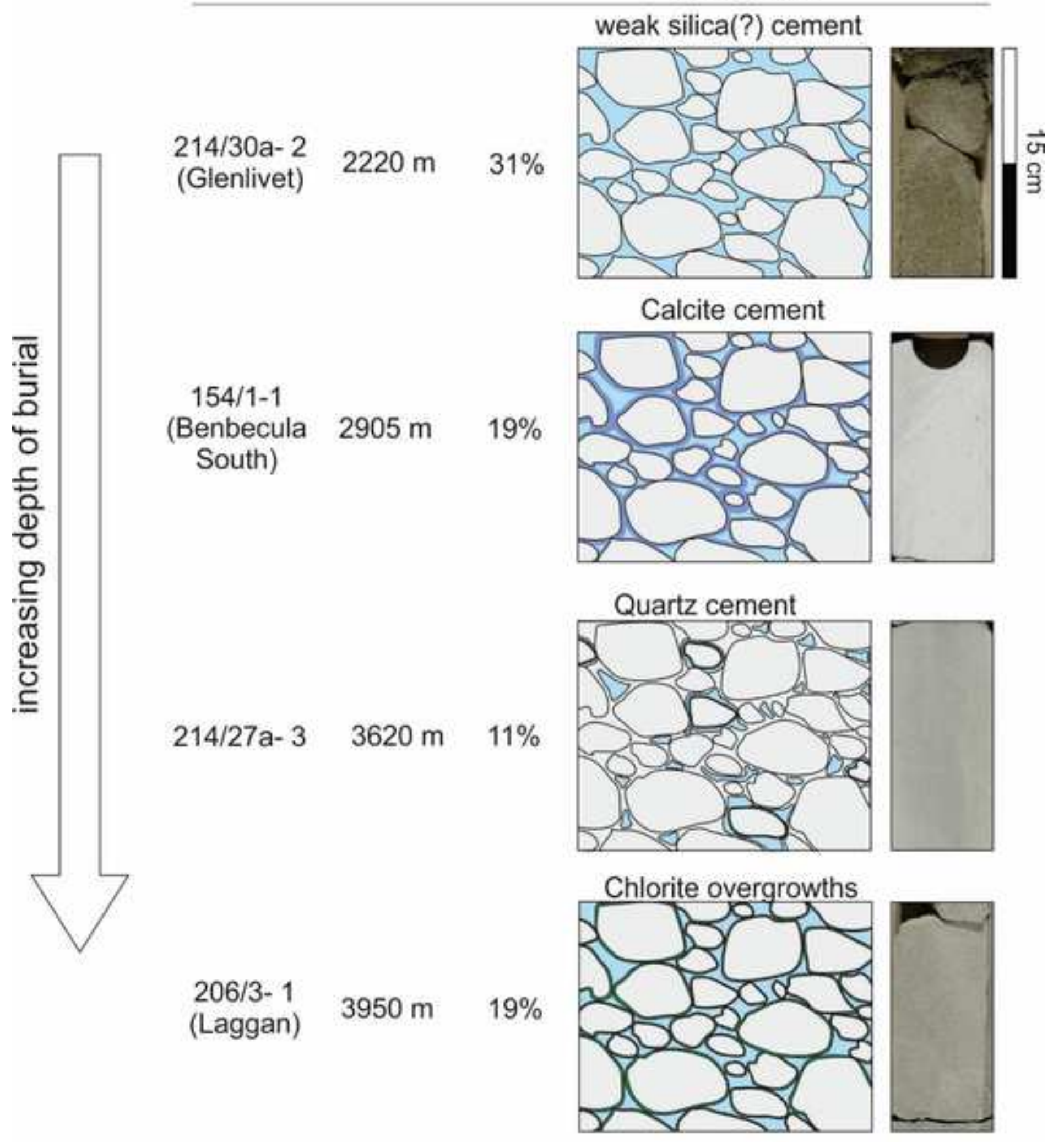




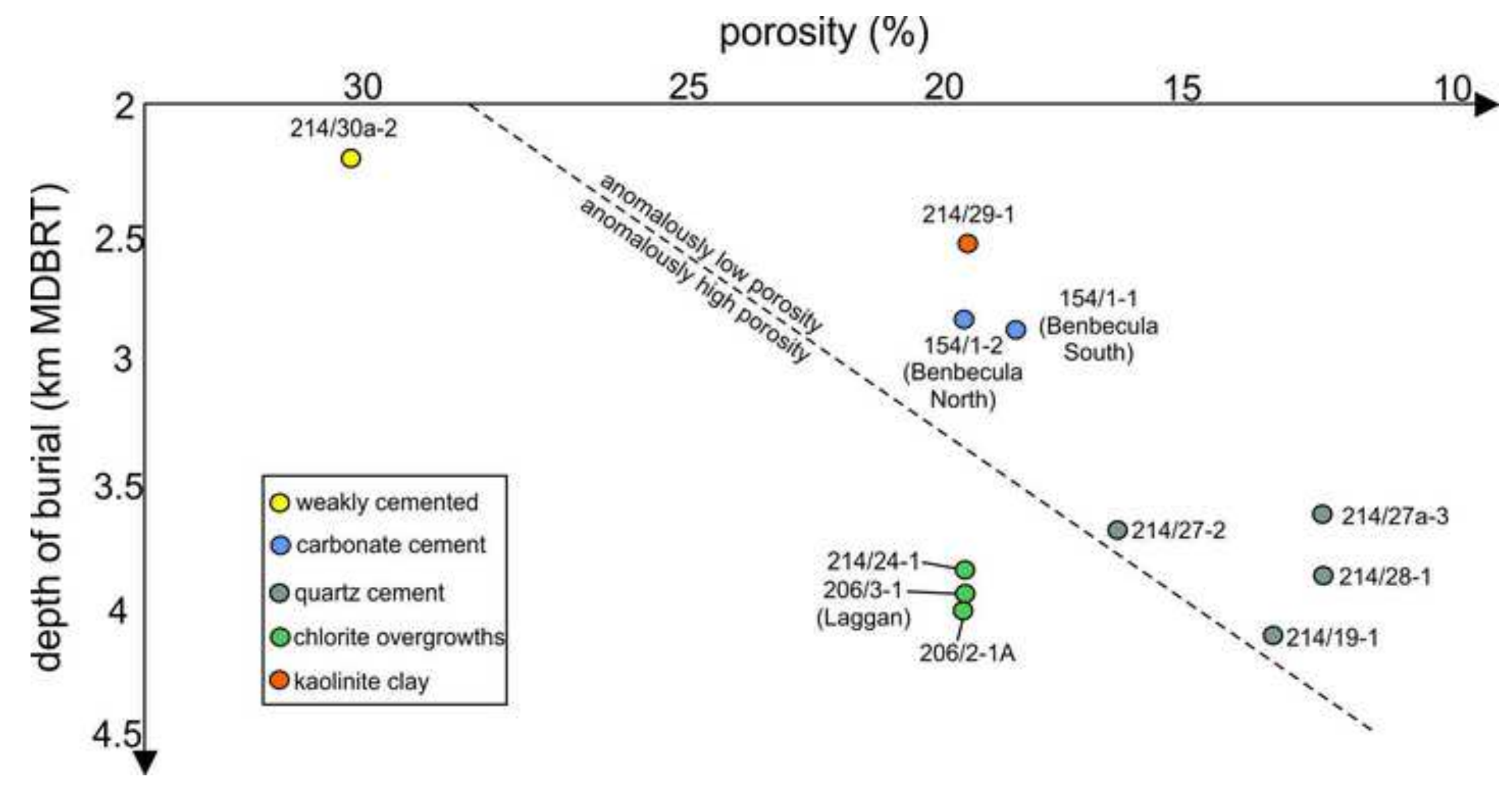

porosity (\%) 


\section{A)}
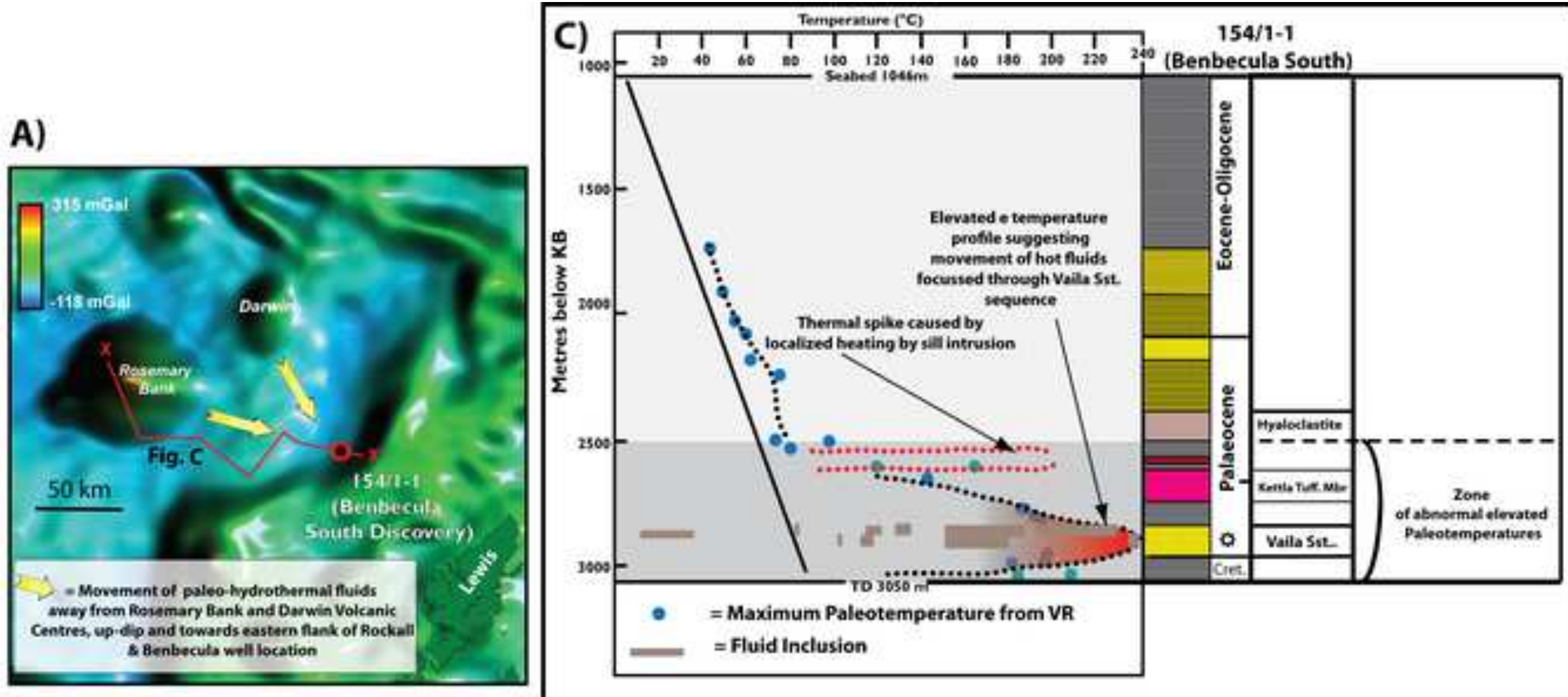

B)

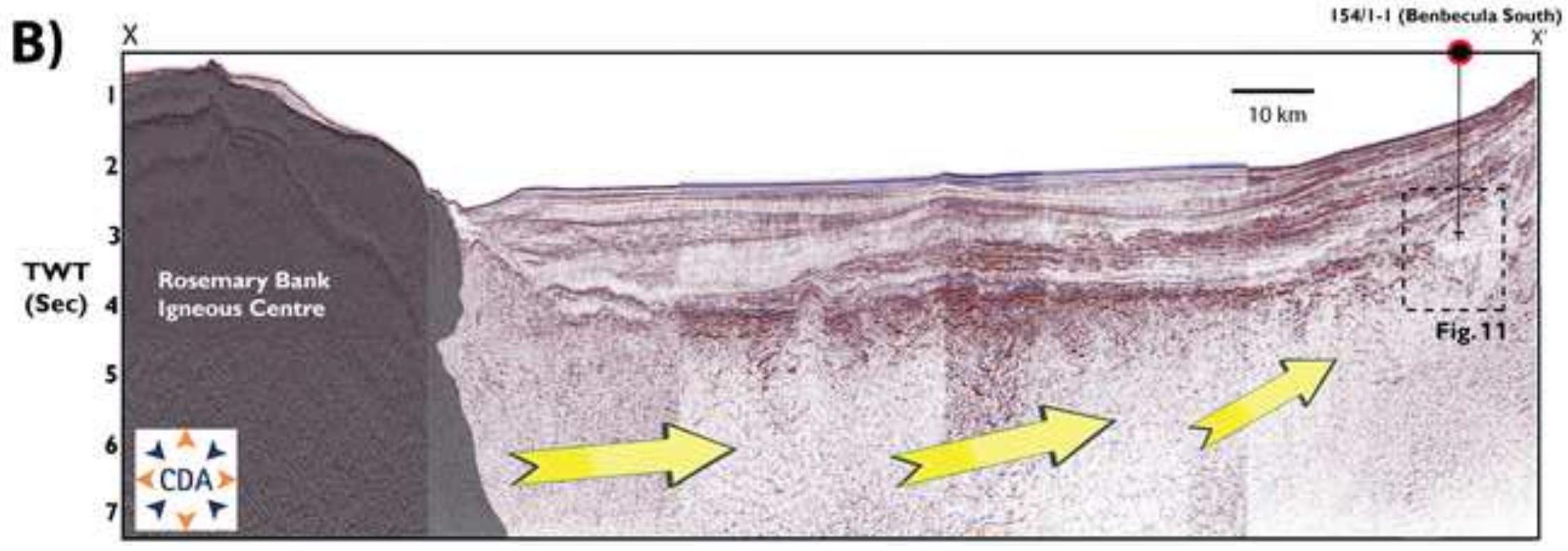




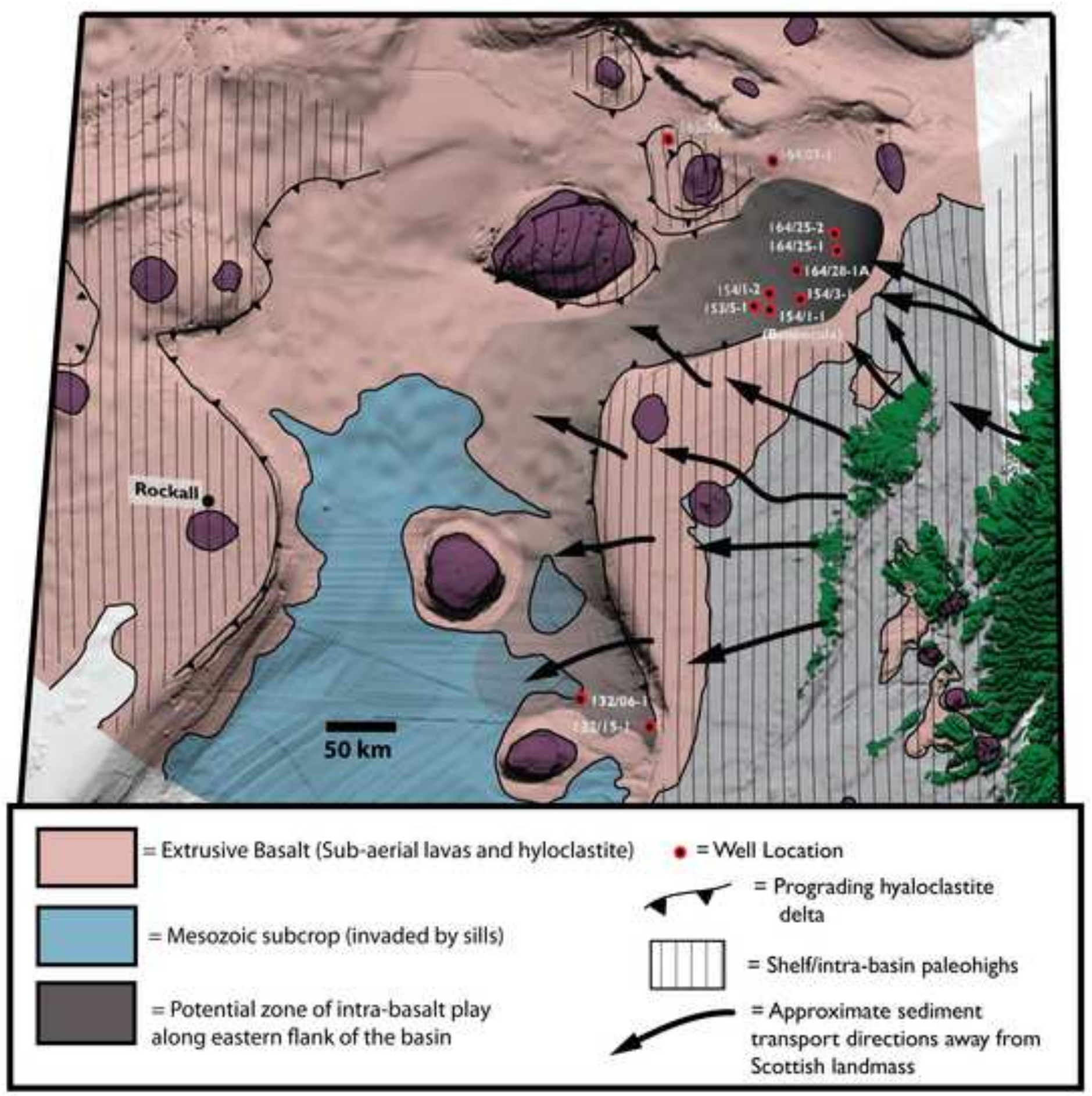

